\title{
Antioxidant and Antidiabetic Effects of Flavonoids: A Structure-Activity Relationship Based Study
}

\author{
Murni Nazira Sarian, ${ }^{1}$ Qamar Uddin Ahmed, ${ }^{1}$ Siti Zaiton Mat So'ad, ${ }^{1}$ \\ Alhassan Muhammad Alhassan, ${ }^{1}$ Suganya Murugesu, ${ }^{1}$ Vikneswari Perumal, ${ }^{1}$ \\ Sharifah Nurul Akilah Syed Mohamad, ${ }^{1}$ Alfi Khatib, ${ }^{1}$ and Jalifah Latip ${ }^{2}$ \\ ${ }^{1}$ Department of Pharmaceutical Chemistry, Faculty of Pharmacy, International Islamic University Malaysia (IIUM), \\ 25200 Kuantan, Pahang, Malaysia \\ ${ }^{2}$ School of Chemical Sciences and Food Technology, Faculty of Science and Technology, Universiti Kebangsaan Malaysia (UKM), \\ 46300 Bangi, Selangor, Malaysia
}

Correspondence should be addressed to Qamar Uddin Ahmed; quahmed@iium.edu.my and Jalifah Latip; jalifah@ukm.edu.my

Received 23 July 2017; Revised 21 September 2017; Accepted 12 October 2017; Published 28 November 2017

Academic Editor: Isabelle Chevalot

Copyright (C) 2017 Murni Nazira Sarian et al. This is an open access article distributed under the Creative Commons Attribution License, which permits unrestricted use, distribution, and reproduction in any medium, provided the original work is properly cited.

\begin{abstract}
The best described pharmacological property of flavonoids is their capacity to act as potent antioxidant that has been reported to play an important role in the alleviation of diabetes mellitus. Flavonoids biochemical properties are structure dependent; however, they are yet to be thoroughly understood. Hence, the main aim of this work was to investigate the antioxidant and antidiabetic properties of some structurally related flavonoids to identify key positions responsible, their correlation, and the effect of methylation and acetylation on the same properties. Antioxidant potential was evaluated through dot blot, 2,2-diphenyl-1-picrylhydrazyl (DPPH) radical scavenging, $\mathrm{ABTS}^{+}$radical scavenging, ferric reducing antioxidant power (FRAP), and xanthine oxidase inhibitory (XOI) assays. Antidiabetic effect was investigated through $\alpha$-glucosidase and dipeptidyl peptidase-4 (DPP-4) assays. Results showed that the total number and the configuration of hydroxyl groups played an important role in regulating antioxidant and antidiabetic properties in scavenging DPPH radical, $\mathrm{ABTS}^{+}$radical, and FRAP assays and improved both $\alpha$-glucosidase and DPP- 4 activities. Presence of C-2-C-3 double bond and C-4 ketonic group are two essential structural features in the bioactivity of flavonoids especially for antidiabetic property. Methylation and acetylation of hydroxyl groups were found to diminish the in vitro antioxidant and antidiabetic properties of the flavonoids.
\end{abstract}

\section{Introduction}

Flavonoids, a group of hydroxylated phenolic substances known to be potent free radical scavengers, have attracted a tremendous interest as possible therapeutics against free radical mediated diseases, particularly diabetes mellitus [1-3]. Flavonoids are benzo- $\gamma$-pyrone derivatives and are known to be synthesized by plants in response to microbial infection. They (Figure 1) are classified according to their side group positions and substitutions. The chemical nature of these polyphenolic substances depends on their structural class, degree of hydroxylation, other substitutions and conjugations, and degree of polymerization. Their different pharmacological effects are mostly structure dependent. The protective effects of flavonoids in biological systems are ascribed to their capacity to transfer hydrogen or electrons free radical [4], activate antioxidant enzymes [5], chelate metal catalyst [6], reduce $\alpha$-tocopherol radicals [7], and inhibit oxidases [8].

Reactive oxygen species (ROS) are capable of oxidizing cellular proteins, nucleic acids, and lipids. Studies and clinical evidences have shown that the generation of ROS increases in both types of diabetes and that the onset of diabetes is closely associated with oxidative stress mainly through oxidation, nonenzymatic protein glycation, and oxidative degradation of glycated proteins $[9,10]$. Elevation of ROS such as mitochondrial superoxide in endothelial cell [11] and endoplasmic reticulum stress [8] followed by reduced antioxidant defense mechanism provokes cellular and enzyme damage, and lipid 


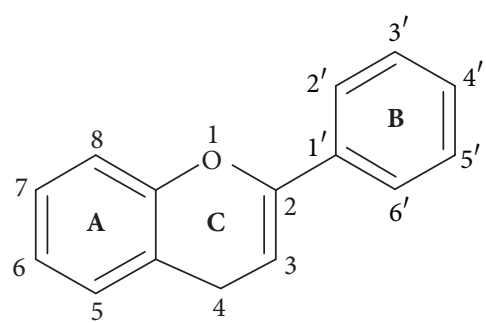

FIGURE 1: Basic structure of flavonoids consists of a fused A and C rings, with phenyl $\mathrm{B}$ ring attached through its $1^{\prime}$ position to the 2 position of the $\mathrm{C}$ ring.

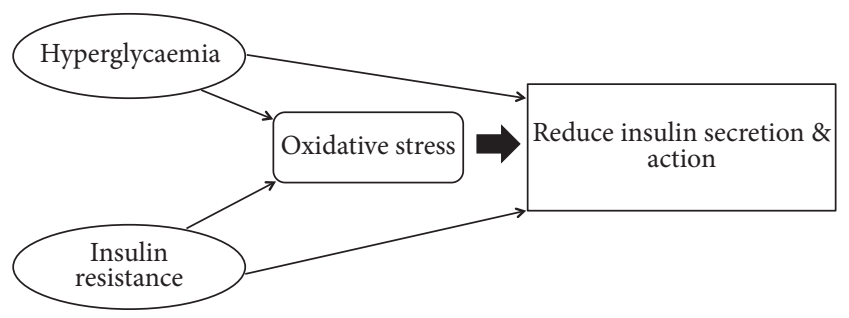

FIGURE 2: Relationship of hyperglycaemia, insulin resistance, and oxidative stress.

peroxidation which subsequently lead to the development and progression of insulin resistance and hyperglycaemia [12]. Both hyperglycaemia and insulin resistance are linked to the generation of an oxidative stress, which can also produce an impaired insulin action (Figure 2). It has been shown that hyperlipidemia acts to generate oxidative stress in the mitochondria through the same pathway as hyperglycemia [13]. Studies have also shown that antioxidants are able to improve insulin action [14-16]. Since the early 1980s, the potential effects of flavonoids in diabetes mellitus have been studied eminently for type 2 compared to that for type 1 $[13,17]$. Flavonoids showing potent antioxidant activity have been suggested to be beneficial in the management of diabetes mellitus. The ability of antioxidants to protect against the deleterious effects of hyperglycemia and also to enhance glucose metabolism and uptake should be considered as a lead alternative in diabetes mellitus treatment. On top of their antioxidative effect, flavonoids may act on biological targets involved in type 2 diabetes mellitus such as $\alpha$ glycosidase and DPP-4. Being a radical scavenger, flavonoids can effectively prevent and/or manage type 2 diabetes mellitus. Since flavonoids are directly associated with human dietary ingredients and health, there is a need to evaluate structure activity relationship with regard to understanding their functions more accurately.

Several traditional medicinal plants rich in flavonoid contents have been reported to exert antioxidant and antidiabetic effects [18-20]. In this regard, Tetracera indica Merr. and Tetracera scandens (L.) Merr. (family Dilleniaceae) have been reported to contain rich amount of flavonoids [8, 21-23]. $T$. indica commonly known as akar mempelas paya and $T$. scandens commonly known as mempelas kasar are traditionally used to manage diabetes mellitus in different parts of
Malaysia [21-24]. In this research work, different bioassays were applied to evaluate the antioxidant and antidiabetic activities of flavonoids isolated from T. indica and T. scandens and their semisynthetic and structural analogs. Since these compounds are based on the flavonoids molecules, configuration and type of substitution may influence the antioxidant and antidiabetic activities. Hence, this study was aimed at investigating the role of hydroxyl, methoxy, and acetate groups in flavonoids structure owing to the fact that the antioxidant and antidiabetic potentials of flavonoids are affected by the presence of different functionalities about their nuclear structure. Therefore, attempts were made to investigate their structures' relationship and correlation for antioxidant and antidiabetic effects. Further advancement of this research work may lead to the development of nutritional product and semisynthetic analogs that retain substantial antidiabetic capacity with minimal adverse effects.

\section{Materials and Methods}

2.1. Chemicals, Reagents, and Solvents. 8-Hydroxy-7-methoxyflavone, $(+)$-catechin, (-)-epicatechin, quercetin (control), ascorbic acid, trolox, ABTS+ radical, potassium persulphate, xanthine, xanthine oxidase, anhydrous potassium carbonate, anhydrous sodium sulphate, acetic anhydride, pyridine, and 2,2-diphenyl-1-picrylhydrazyl (DPPH) were purchased from Sigma-Aldrich (Singapore). 2,4,6-Tris(2pyridyl)-s-triazine (TPTZ, 99\%), iron (III) chloride hexahydrate, and sodium acetate were purchased from SigmaAldrich (St. Louis, MO, USA). Allopurinol was purchased from Nacalai Tesque (Japan). Dipeptidyl peptidase-4 (DPP4) inhibitor assay kit was purchased from Cayman (Michigan, USA). $\alpha$-Glucosidase from Saccharomyces cerevisiae was purchased from Megazyme (Ireland). Methanol, chloroform, ethyl acetate, acetone, ethanol, dimethyl sulphoxide (DMSO), dimethyl sulphate, and thin layer chromatography (TLC) plates were purchased from Merck (Germany).

2.2. Collection and Preparation of Plant Material. Fresh leaves $(10 \mathrm{~kg})$ of T. indica and T. scandens each were collected from the local garden Taman Pertanian, Indera Mahkota, 25200 Kuantan, Pahang, Malaysia. Identification of the plants was performed by the taxonomists of Taman Pertanian and Kulliyyah of Pharmacy, IIUM. Later, the samples of both plants were deposited in the herbarium of Kulliyyah of Pharmacy, IIUM, Kuantan, to get their voucher specimen numbers (NMPC-QSTI39 and NMPC-QU24) for the future references. The same plant materials were compared with the already deposited specimens of the same plants in the herbarium of Kulliyyah of Pharmacy, IIUM. $5 \mathrm{~kg}$ of powdered material of each plant's leaves was macerated in $20 \mathrm{~L}$ analytical grade distilled $\mathrm{MeOH}$ for $24 \mathrm{~h}$ at room temperature in the dark, filtered, and concentrated in a reduced pressure using Buchi rotary evaporator. Recovered $\mathrm{MeOH}$ was again poured into the already extracted powdered material, filtered, and concentrated to remove the entire solvent. The whole process was repeated about four times till the plant material stopped giving coloration as well as to ensure maximum yield of methanol soluble (bioactive) compounds from the plants 
material. The concentrated extracts free of methanol were further subjected to freeze-drying process to remove water content from the resultant extracts to make them completely dried. Finally, $\mathrm{MeOH}$ extracts of the leaves of T. indica (250 g) and $T$. scandens $(180 \mathrm{~g})$ were successfully obtained.

\subsection{Fractionation of T. indica and T. scandens Leaves $\mathrm{MeOH}$} Extracts and Flavonoids Isolation. Conventional maceration, solvent extraction, silica gel, and sephadex $\mathrm{LH}_{20}$ column chromatographies methods were effectively used to isolate some desirable flavonoids from the leaves $\mathrm{MeOH}$ extracts of T. indica and T. scandens, respectively. Initially, flavonoids were isolated from the leaves $\mathrm{MeOH}$ extract of $T$. indica as has been briefly described below. Fractionation of the leaves $\mathrm{MeOH}$ extract was done using separatory funnel with regard to removing undesirable substances initially. Typically, methanol extract $(250 \mathrm{~g})$ was dissolved in distilled water and treated with hexane until the hexane portion became clearly separated or visible. Collected hexane portion was recovered through rotary evaporator. The combined hexane fraction $(15.7 \mathrm{~g})$ was considered as nonpolar extract (hexane soluble compounds) of the leaves of T. indica. Secondly, the remaining hexane insoluble portion was treated with ethyl acetate (EtOAc) in the same manner. After concentrating through rotary evaporator, the collected fraction was considered as EtOAc fraction $(85.45 \mathrm{~g})$ of the leaves methanol extract of T. indica. Finally, ethyl acetate insoluble part was treated with butanol by following the same procedure to get butanol fraction $(40.25 \mathrm{~g})$ of the leaves methanol extract of $T$. indica. Initially, isolation of flavonoids from EtOAc fraction was performed by silica gel $60(63-200 \mu \mathrm{m})$ column chromatography followed by small preparative columns containing silica gel $60(63-200 \mu \mathrm{m})$ and sephadex LH 20. Ethyl acetate fraction of $T$. indica leaves $\mathrm{MeOH}$ extract using repeated silica gel and sephadex LH 20 column chromatographies afforded three different flavones, namely, wogonin, norwogonin, and techtochrysin. Similar aforesaid method was strictly followed to isolate some desirable already reported flavonoids from the T. scandens leaves $\mathrm{MeOH}$ extract that afforded two flavones (hypolaetin and isoscutellarein) and two flavonols (kaempferol and quercetin) after repeated silica gel and sephadex $\mathrm{LH}_{20}$ column chromatographies and recrystallization techniques [24]. These compounds structures were characterized by spectroscopic analysis (NMR, IR, UV, and mass spectrometry). Their spectral data were further compared with the previously reported spectral data of the similar compounds already isolated from different plants to ensure their correct structures.

\subsection{Semisynthetic Analog}

2.4.1. Methylation of Wogonin. Wogonin (100 mg) was methylated with dimethyl sulphate and anhydrous potassium carbonate in dry acetone on water bath for $3 \mathrm{~h}$; upon completing the reaction, product was filtered, dried, and treated with chloroform. Chloroform soluble fraction was extracted with water and dried over anhydrous sodium sulphate; then it was put for crystallization with ethanol to get pure form of methyl ether of wogonin as needle shaped yellow crystals [25].

2.4.2. Acetylation of Wogonin and Norwogonin. Wogonin and norwogonin $(100 \mathrm{mg})$ were separately acetylated with pyridine $(5 \mathrm{~mL})$ and acetic anhydride $(15 \mathrm{~mL})$ on the water bath for at least $4 \mathrm{~h}$. Upon completing the reaction, mixture was poured slowly into crushed ice with continuous stirring. After some time, the precipitation was dissolved in chloroform and crystallized from ethanol as white needle shaped crystals [25].

2.5. Rapid Screening of Radical Scavenging Activity by Dot Blot Assay. An aliquot $(20 \mu \mathrm{L})$ of each dilution of each group was carefully loaded on a $10 \times 10 \mathrm{~cm}^{-1}$ TLC plate and allowed to dry for $10 \mathrm{~min}$. Drops of each sample were loaded in the order of decreased concentration along the 16 columns. The staining of the silica plate was based on the procedure of Soler-Rivas et al. [26]. The sheet bearing the dry spots was placed upside down for $10 \mathrm{~s}$ in a $0.4 \mathrm{mM}$ $\mathrm{DPPH}$ solution in $\mathrm{MeOH} / 0.05 \%$ of $\mathrm{DPPH}$ in $\mathrm{MeOH}$. Stained silica plate revealed a purple background with yellow spots at the location of the drops, which showed radical scavenger capacity. The intensity of the yellow color depends upon the amount and nature of radical scavenger present in the flavonoids.

2.6. 2,2-Diphenyl-1-picrylhydrazyl (DPPH) Radical Scavenging Assay. Each sample's stock solution was diluted to final concentrations of $1000-0.4889 \mu \mathrm{g} / \mathrm{mL}$ in $\mathrm{MeOH}$. A total of $1 \mathrm{~mL}$ of a $0.3 \mathrm{mM}$ DPPH methanolic solution was added to $2.5 \mathrm{~mL}$ of sample solution of different concentrations and allowed to react at room temperature. After $30 \mathrm{~min}$, the absorbance (Abs) values were measured at $517 \mathrm{~nm}$ with a microplate reader (Tecan NanoQuant Infinite M200, Switzerland) and converted into the percentage antioxidant activity using the following equation described previously [26-28]:

$\%$ antioxidant activity

$$
\begin{aligned}
= & 100-\frac{[\text { Abs }(\text { sample })-\text { Abs }(\text { sample blank })]}{[\text { Abs (control })-\text { Abs (control blank })]} \\
& \times 100 .
\end{aligned}
$$

$\mathrm{MeOH}+$ compound solution was used as a blank, while DPPH solution plus $\mathrm{MeOH}$ was used as a negative control. The positive controls were DPPH solution plus $1 \mathrm{mM}$ ascorbic acid. The $\mathrm{IC}_{50}$ values were calculated by linear regression of plots. The average percent of scavenging capacity was taken from three replicates.

2.7. ABTS $^{+}$Radical Scavenging Assay. An improved $\mathrm{ABTS}^{+}$ radical decolorization assay was carried out involving direct production of the blue/green $\mathrm{ABTS}^{+}$chromophore through the reaction between ABTS and potassium persulfate. Addition of antioxidant to the preformed radical cation reduces it to ABTS to an extent on a time scale depending on the antioxidant activity, the concentration of the antioxidant, and the duration of the reaction. $1 \mathrm{ml}$ ABTS was dissolved in 
water to make $7 \mathrm{mM}$ concentration of the resultant solution. $\mathrm{ABTS}^{+}$radical was produced by reacting ABTS stock solution with $2.45 \mathrm{mM}$ potassium persulfate. The resultant reaction mixture was allowed to stand in the dark at room temperature for $12-16 \mathrm{~h}$ before being used. The $\mathrm{ABTS}^{+}$ radical solution was diluted with $\mathrm{MeOH}$ to an absorbance of $0.7( \pm 0.02)$ at $734 \mathrm{~nm}$. Then, $100 \mu \mathrm{l}$ of sample at various concentrations $(1000-0.4889 \mu \mathrm{g} / \mathrm{mL})$ was mixed with $100 \mu \mathrm{L}$ of diluted $\mathrm{ABTS}^{+}$radical. Each concentration was analyzed in triplicate and the percentage decrease of absorbance at $734 \mathrm{~nm}$ with a microplate reader (Tecan NanoQuant Infinite M200, Switzerland) was calculated for each point and the antioxidant capacity of the tested compounds was expressed as percent inhibition (\%). The radical scavenging activity of the compounds was measured according to the following equation [29]:

$$
\% \text { inhibition }=\frac{A(\text { control })-A(\text { sample })}{A(\text { control })} \times 100 .
$$

$\mathrm{IC}_{50}$ values were calculated by linear regression of plots, and the average percent of scavenging capacity was taken from three replicates. Trolox was used as a standard in comparison for the determination of the antioxidant activity of the flavonoids.

2.8. Xanthine Oxidase Inhibitory Assay (XOI) . XO catalyzes the oxidation of hypoxanthine to xanthine and subsequently to uric acid. The inhibition of $\mathrm{XO}$ reduces both vascular oxidative stress and circulating levels of uric acid. This assay is based on the fact that the superoxide anions are generated by the xanthine. The xanthine oxidase inhibitory activity was measured spectrophotometrically (Tecan NanoQuant Infinite M200, Switzerland) at $295 \mathrm{~nm}$ under aerobic condition with slight modification [30-32]. The reaction mixture contained $50 \mathrm{mM}$ phosphate buffer ( $\mathrm{pH} 7.5$ ), $0.15 \mathrm{mM}$ xanthine (substrate), and $0.3 \mathrm{U} / \mathrm{mL}$ enzymes (xanthine oxidase from buttermilk). Samples were prepared by dissolving $1 \mathrm{mg}$ in 5\% DMSO in $\mathrm{MeOH}$ which gives sample concentration of $144.0 \mu \mathrm{g} / \mathrm{mL}$ in assay. The final concentration of $\mathrm{MeOH}$ in the reaction mixture did not exceed $1 \%(\mathrm{v} / \mathrm{v})$, of which concentration did not influence the activity of xanthine oxidase. The absorption increment at $295 \mathrm{~nm}$ indicates the formation of $1 \mathrm{mmol}$ of uric acid $/ \mathrm{min}$ at $25^{\circ} \mathrm{C}$. Allopurinol $(5.0-100 \mu \mathrm{g} / \mathrm{mL})$, a known XO inhibitor [21], was used as the positive control. All determination was done in triplicate and half maximal concentration $\left(\mathrm{IC}_{50}\right)$ values were calculated from the percentage of inhibition. XO inhibition activity was expressed as the percentage inhibition of $\mathrm{XO}$ as follows:

$$
\% \text { of inhibition }=\frac{\operatorname{Abs}[(A-B)-(C-D)]}{\operatorname{Abs}(A-B)} \times 100,
$$

where $A$ is the negative control with $B$ as the blank of $A$ which is without the enzyme and the sample while $C$ is the activity of the sample with enzyme with $D$ as the blank of the sample without enzyme [33].

2.9. Ferric Reducing Antioxidant Power (FRAP). This assay was based on the reduction of the ferric tripyridyltriazine
(Fe III-TPTZ) complex to the ferrous ion (Fe II) at a low $\mathrm{pH}$ forming an intense blue color. In the FRAP assay, compounds that are rich in antioxidant effect exert their action by breaking the free radical chain by donating a hydrogen atom. Briefly, ferric reducing antioxidant power (FRAP) reagent $(2.5 \mathrm{~mL}$ of a $10 \mathrm{mM}$ TPTZ solution in $40 \mathrm{mM} \mathrm{HCl}, 2.5 \mathrm{~mL}$ of $20 \mathrm{mM} \mathrm{FeCl}_{3}$, and $25 \mathrm{~mL}$ of $0.1 \mathrm{M}$ acetate buffer $\mathrm{pH} 3.6$ ) was prepared and incubated for $10 \mathrm{~min}$ at $37^{\circ} \mathrm{C}$. Then $20 \mu \mathrm{L}$ of each compound and ascorbic acid (standard) and $40 \mu \mathrm{L}$ of FRAP reagent were added to $140 \mu \mathrm{L}$ of distilled water in a 96well plate producing a blue-colored solution. The solutions were kept at room temperature for $20 \mathrm{~min}$ in the dark and then measured at $593 \mathrm{~nm}$ with a microplate reader (Tecan, Switzerland) using a reagent blank composed of $40 \mu \mathrm{L}$ of FRAP reagents in $200 \mu \mathrm{L}$ of distilled water [34]. A calibration curve was prepared with a serial dilution of ascorbic acid (standard). The total antioxidant capacity was calculated by interpolating the measured absorbance of the calibration curve and expressed as ascorbic acid equivalents. The results were corrected for dilution and expressed as AAE $\mu \mathrm{g}$ of ascorbic acid/g.

2.10. $\alpha$-Glucosidase Inhibitory Assay. $\alpha$-Glucosidase inhibitory activity of the flavonoids was carried out according to the standard method with minor modification [35]. Briefly, $1 \mathrm{mg}$ of each sample was dissolved in $10 \%$ of DMSO and $\mathrm{MeOH}$ as the stock solution, while, for the positive control, $1 \mathrm{mg}$ of quercetin (Sigma-Aldrich, Singapore) was dissolved in $1 \mathrm{~mL}$ of DMSO. A solution of $30 \mathrm{mM}$ phosphate buffer ( $\mathrm{pH}$ 6.5) was used to prepare stock solution of the sample to form a final concentration of $160 \mu \mathrm{g} / \mathrm{mL}$. Then, $10 \mu \mathrm{L} /$ well of sample was mixed with $15 \mu \mathrm{L} /$ well of $\alpha$-glucosidase from Saccharomyces cerevisiae (Megazyme, Ireland). $50 \mathrm{mM}$ buffer ( $\mathrm{pH}$ 6.5) was used to prepare the enzyme solution. Then, $115 \mu \mathrm{L} /$ well of $30 \mathrm{mM}$ buffer ( $\mathrm{pH}$ 6.5) was added and incubated for $5 \mathrm{~min}$ at room temperature. Then, $75 \mu \mathrm{L} /$ well of PNP-glucoside was added to initiate reaction and incubated at room temperature for $15 \mathrm{~min}$. Finally, about $50 \mu \mathrm{L}$ glycine at $\mathrm{pH} 10$ was added to stop the reaction. The final volume of $250 \mu \mathrm{L}$ of compound, positive control, enzyme, $30 \mathrm{mM}$ buffer, and substrate was located in 96-well microplate. The absorbance (Abs) was measured using microplate reader (Tecan NanoQuant Infinite M200, Switzerland) at $405 \mathrm{~nm}$ to represent the amount of p-nitrophenol released from PNP-glucoside. The $\mathrm{IC}_{50}$, the sample concentration needed to inhibit $50 \% \alpha$-glucosidase, was determined using linear regression analysis. The equation given below was used to calculate the inhibitory activity (\%):

$$
\begin{aligned}
& \text { Inhibitory activity }(\%) \\
& \qquad=\left[\frac{(\text { Abs control }- \text { Abs sample })}{(\text { Abs control })}\right] \times 100 \% .
\end{aligned}
$$

2.11. Dipeptidyl Peptidase IV (DPP-4) Inhibitory Assay. Dipeptidyl peptidase (IV) inhibitors work by inhibiting the action of this enzyme, thereby prolonging the activity of incretins that play an important role in insulin secretion and blood glucose control regulation. DPP-4 inhibitory assay was performed as per the standard method (Cayman, USA). 
Firstly, $1 \mathrm{mg}$ of sample was dissolved in 10\% of DMSO and $\mathrm{MeOH}$ as the stock solution. For initial activity (100\%), $10 \mu \mathrm{L}$ of $\mathrm{MeOH}, 30 \mu \mathrm{L}$ of diluted assay buffer, and $10 \mu \mathrm{L}$ of diluted DPP-4 (Cayman, USA) were added to 96-well microplate. For positive control, $10 \mu \mathrm{L}$ of sitagliptin was added with $30 \mu \mathrm{L}$ of diluted assay buffer and $10 \mu \mathrm{L}$ of diluted DPP- 4 . For background well, $10 \mu \mathrm{L}$ of $\mathrm{MeOH}$ and $40 \mu \mathrm{L}$ of diluted assay buffer were added. Then, $10 \mu \mathrm{L}$ of prepared sample and $30 \mu \mathrm{L}$ of diluted assay buffer were added with $10 \mu \mathrm{L}$ of diluted DPP-4. After that, $50 \mu \mathrm{L}$ of substrate solution was added to all wells to initiate the reaction and further incubated in the dark at $37^{\circ} \mathrm{C}$ for $30 \mathrm{~min}$. Finally, plate was read at $360 \mathrm{~nm}$ of excitation wavelength and $465 \mathrm{~nm}$ of emission wavelength using fluorescence microplate reader (Perkin Elmer, Germany). All determinations were done in triplicate and half maximal concentration $\left(\mathrm{IC}_{50}\right)$ values were calculated from the percentage of inhibition based on the linear regression analysis. The equation given below was applied to calculate the inhibitory activity (\%):

$$
\begin{aligned}
& \text { Inhibitory activity (\%) } \\
& \qquad=\left[\frac{(\text { Initial Activity }- \text { Sample })}{(\text { Initial Activity })}\right] \times 100 \% .
\end{aligned}
$$

2.12. Statistical Analysis. Data were collected and expressed as the mean \pm standard error of mean (SEM) of three independent experiments and analyzed for statistical significance from each control. The data were tested for statistical differences by one-way ANOVA followed by Tukey's and Dunnett's multiple comparison tests of MiniTab (version 18). The criterion for significance was set at $p<0.05$.

\section{Results}

\subsection{Spectral Data of Tested Flavonoids}

Wogonin (5,7-Dihydroxy-8-methoxyflavone, Norwogonin 8Methyl Ether). ${ }^{1} \mathrm{H}-\mathrm{NMR}\left[600 \mathrm{MHz}\right.$, Acetone- $\mathrm{d}_{6}, \delta$ (ppm)]: 6.67 (s, 1H, H-3), 6.20 (s, 1H, H-6), 7.97 (m, 2H, H-2 / $/ \mathrm{H}^{\prime} 6^{\prime}$ ), 7.50 (m, 3H, H-3'/ $\left.4^{\prime} / \mathrm{H}^{\prime}\right), 3.84$ (s, $\left.-\mathrm{OCH}_{3}, 3 \mathrm{H}, \mathrm{H}-8 \mathrm{a}\right), 12.43$ (s, 1H, OH-5) [36].

Methyl Ether of Wogonin (5,7,8-Trimethoxyflavone). ${ }^{1} \mathrm{H}-\mathrm{NMR}$ $\left[600 \mathrm{MHz}\right.$, Acetone- $\left._{6}, \delta(\mathrm{ppm})\right]: 6.77(\mathrm{~s}, 1 \mathrm{H}, \mathrm{H}-3), 6.73$ (s, 1H, H-6), $8.11\left(\mathrm{~m}, 2 \mathrm{H}, \mathrm{H}-2^{\prime} / \mathrm{H}-6^{\prime}\right), 7.63(\mathrm{~m}, 3 \mathrm{H}, \mathrm{H}-$ $3^{\prime} / \mathrm{H}^{\prime} / \mathrm{H}^{\prime}$ ), 3.95 (s, 2x- $\left.\mathrm{OCH}_{3}, 6 \mathrm{H}, \mathrm{H}-7 \mathrm{a}, \mathrm{H}-8 \mathrm{a}\right), 4.07$ (s, $\left.\mathrm{OCH}_{3}, 3 \mathrm{H}, \mathrm{H}-5 \mathrm{a}\right)$ [37].

Acetate of Wogonin (5,7-Diacetoxy-8-methoxyflavone). ${ }^{1} \mathrm{H}$ NMR [600 MHz, Acetone- $\left.\mathrm{d}_{6}, \delta(\mathrm{ppm})\right]: 6.97$ (s, 1H, H-3), 6.77 (s, 1H, H-6), 8.10 (m, 2H, H-2 $\left./ \mathrm{H}^{\prime} 6^{\prime}\right), 7.64$ (m, 3H, H$3^{\prime} / \mathrm{H}^{\prime} / \mathrm{H}^{\prime}$ ), 4.09 (s, $\left.-\mathrm{OCH}_{3}, 3 \mathrm{H}, \mathrm{H}-8 \mathrm{a}\right), 2.41$ (s, $-\mathrm{OCOCH}_{3}$, $3 \mathrm{H}), 2.34$ (s, $\left.-\mathrm{OCOCH}_{3}, 3 \mathrm{H}\right)$ [25].

Techtochrysin (5-Hydroxy-7-methoxyflavone). ${ }^{1} \mathrm{H}-\mathrm{NMR}$ [600 MHz, MeOD- $\left.\mathrm{d}_{4}, \delta(\mathrm{ppm})\right]: 6.43$ (s, 1H, H-3), 6.34 (d, $J=2.4 \mathrm{~Hz}, 1 \mathrm{H}, \mathrm{H}-6), 6.50(\mathrm{~d}, J=2.4,1 \mathrm{H}, \mathrm{H}-8), 7.87(\mathrm{dd}$,
$\left.J=1.8,4.2 \mathrm{~Hz}, 2 \mathrm{H}, \mathrm{H}-2^{\prime} / \mathrm{H}-6^{\prime}\right), 7.44\left(\mathrm{~m}, 3 \mathrm{H}, \mathrm{H}-3^{\prime} / \mathrm{H}-4^{\prime} / \mathrm{H}^{\prime}\right)$, $3.74\left(\mathrm{~s}, 3 \mathrm{H}, 7-\mathrm{OCH}_{3}\right)[38]$.

Chrysin (5,7-Dihydroxyflavone). ${ }^{1} \mathrm{H}-\mathrm{NMR}(600 \mathrm{MHz}$, Acetone- $\left.\mathrm{d}_{6}, \delta(\mathrm{ppm})\right): 6.31(\mathrm{~d}, J=2.2 \mathrm{~Hz}, \mathrm{H}-6), 6.60(\mathrm{~d}, J=$ $2.2 \mathrm{~Hz}, \mathrm{H}-8$ ), 6.80 (s, H-3), 7.63 (m, H-3 $3^{\prime} 4^{\prime}, 5^{\prime}$ ), 8.09 (dd, $J=1.7$ and $\left.7.45 \mathrm{~Hz}, \mathrm{H}-2^{\prime}, 6^{\prime}\right), 12.91(\mathrm{~s}, 1 \mathrm{H}, \mathrm{OH}-5)$ [39].

Norwogonin (5,7,8-Trihydroxyflavone). ${ }^{1} \mathrm{H}-\mathrm{NMR}[600 \mathrm{MHz}$, Acetone- $\left.\mathrm{d}_{6}, \delta(\mathrm{ppm})\right]: 6.77(\mathrm{~s}, 1 \mathrm{H}, \mathrm{H}-3), 6.36(\mathrm{~s}, 1 \mathrm{H}, \mathrm{H}-6), 7.37$ (m, 3H, H-3 $3^{\prime} / \mathrm{H}^{\prime} / \mathrm{H}^{\prime}$ ), 8.13 (m, 2H, H-2'/H-6 ${ }^{\prime}$ ), 12.34 (s, $1 \mathrm{H}$, $\mathrm{OH}-5)$ [40].

Acetate of Norwogonin (5,7,8-Triacetoxyflavone). ${ }^{1} \mathrm{H}-\mathrm{NMR}$ [600 MHz, Acetone- $\left.\mathrm{d}_{6}, \delta(\mathrm{ppm})\right]: 6.98(\mathrm{~s}, 1 \mathrm{H}, \mathrm{H}-3), 6.85$ (s, $1 \mathrm{H}, \mathrm{H}-6), 8.00\left(\mathrm{~m}, 2 \mathrm{H}, \mathrm{H}-2^{\prime} / \mathrm{H}-6^{\prime}\right), 7.67$ (m, 3H, H$3^{\prime} / \mathrm{H}^{\prime} / \mathrm{H}^{\prime}$ ), 2.48 (s, $\left.-\mathrm{OCOCH}_{3}, 3 \mathrm{H}\right), 2.37$ (s, $2 \mathrm{x}-\mathrm{OCOCH}_{3}$, $6 \mathrm{H})[25]$.

Isoscutellarein $\quad\left(4^{\prime}, 5,7,8\right.$-Tetrahydroxyflavone $) . \quad{ }^{1} \mathrm{H}-\mathrm{NMR}$ $\left(600 \mathrm{MHz}\right.$, Acetone- $\left.\mathrm{d}_{6}, \delta(\mathrm{ppm})\right): 6.26(1 \mathrm{H}, \mathrm{s}, \mathrm{H}-6) 6.72(1 \mathrm{H}$, $\mathrm{s}, \mathrm{H}-3), 6.93\left(2 \mathrm{H}, \mathrm{d}, J=8.4 \mathrm{~Hz}, 3^{\prime}, 5^{\prime}\right) 8.00(2 \mathrm{H}, \mathrm{d}, J=8.4 \mathrm{~Hz}$, $\left.\mathrm{H}-2^{\prime}, 6^{\prime}\right), 8.81\left(1 \mathrm{H}, \mathrm{s}, \mathrm{OH}-4^{\prime}\right), 10.44(1 \mathrm{H}, \mathrm{s}, \mathrm{OH}-8), 10.59(1 \mathrm{H}$, s, OH-7), 12.36 (1H, s, OH-5) [24].

Hypolaetin $\left(3^{\prime}, 4^{\prime}, 5,7,8\right.$-Pentahydroxyflavone (8-Hydroxyluteolin)). ${ }^{1} \mathrm{H}-\mathrm{NMR}\left(600 \mathrm{MHz}\right.$, Acetone- $\left.\mathrm{d}_{6}, \delta(\mathrm{ppm})\right): 6.27(1 \mathrm{H}$, s, H-6), 6.59 (1H, s, H-3), $6.90\left(1 \mathrm{H}, \mathrm{d}, J=2.4 \mathrm{~Hz}, \mathrm{H}-2^{\prime}\right), 7.43$ $\left(1 \mathrm{H}, \mathrm{d}, J=2.4 \mathrm{~Hz}, \mathrm{H}-5^{\prime}\right), 7.46\left(1 \mathrm{H}, \mathrm{dd}, J=2.4,2.4 \mathrm{~Hz}, \mathrm{H}-6^{\prime}\right)$, $8.77\left(1 \mathrm{H}, \mathrm{s}, \mathrm{OH}-4^{\prime}\right), 9.52\left(1 \mathrm{H}, \mathrm{s}, \mathrm{OH}-3^{\prime}\right), 10.64(1 \mathrm{H}, \mathrm{s}, \mathrm{OH}-7)$, $9.98(1 \mathrm{H}, \mathrm{s}, \mathrm{OH}-8), 12.37(1 \mathrm{H}, \mathrm{s}, \mathrm{OH}-5)$ [24].

Kaempferol (4',3,5,7-Tetrahydroxyflavone). $\quad{ }^{1} \mathrm{H}-\mathrm{NMR}$ $\left(600 \mathrm{MHz}\right.$, Acetone $\left.-\mathrm{d}_{6}, \delta(\mathrm{ppm})\right): 6.27(1 \mathrm{H}, \mathrm{d}, J=1.8 \mathrm{~Hz}$, H6), $6.54(1 \mathrm{H}, \mathrm{d}, J=1.8 \mathrm{~Hz}, \mathrm{H}-8), 7.02(2 \mathrm{H}, \mathrm{dd}, J=2.4,9 \mathrm{~Hz}$, $\left.\mathrm{H}-3^{\prime}, 5^{\prime}\right), 8.16\left(2 \mathrm{H}, \mathrm{dd}, J=1.8,8.4 \mathrm{~Hz}, \mathrm{H}-2^{\prime}, 6^{\prime}\right), 12.17(1 \mathrm{H}, \mathrm{s}$, $\mathrm{OH}-5)$ [24].

Quercetin (3, $\left.3^{\prime}, 4^{\prime}, 5,7-P e n t a h y d r o x y f l a v o n e\right) . \quad{ }^{1} \mathrm{H}-\mathrm{NMR}$ [600 MHz, Acetone- $\left.\mathrm{d}_{6}, \delta(\mathrm{ppm})\right]: 6.28(\mathrm{~d}, J=2.4 \mathrm{~Hz}, 1 \mathrm{H}$, H-6), 6.53 (d, $J=1.8,1 \mathrm{H}, \mathrm{H}-8), 7.01$ (d, $J=8.6 \mathrm{~Hz}, 1 \mathrm{H}, \mathrm{H}-5^{\prime}$ ), $7.71\left(\mathrm{dd}, J=2.0,8.4 \mathrm{~Hz}, 1 \mathrm{H}, \mathrm{H}-6^{\prime}\right), 7.84(\mathrm{~d}, J=2.2 \mathrm{~Hz}, 1 \mathrm{H}$, $\left.\mathrm{H}-2^{\prime}\right), 12.16$ (1H, s, OH-5) [24].

3.2. Rapid Screening of Radical Scavenging Activity by Dot Blot Assay. For the rapid screening of radical scavenging activity, the appearance of yellow spots has a potential value for the indirect evaluation of the antioxidant of the flavonoids. When flavonoids were analyzed, more reactive flavonoids showing strong intensities of white-yellow spots appeared up to several dilutions of $1000 \mu \mathrm{g} / \mathrm{mL}$ of the compounds. Among the groups, isoscutellarein, quercetin, hypolaetin kaempferol, $(+)$-epicatechin, and (+)-catechin showed strong radical scavenging activity; wogonin, norwogonin, chrysin, techtochrysin, and 8-hydroxy-7-methoxyflavone showed intermediate radical scavenging activity, while semisynthetic flavonoids, that is, methyl ether (wogonin) and acetate (wogonin and norwogonin), did not show any spot similar to 


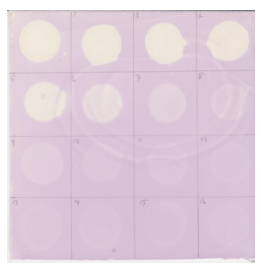

(A.A)

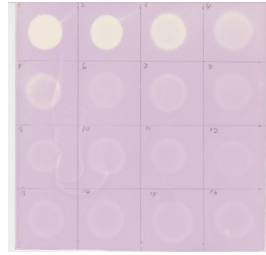

(6)

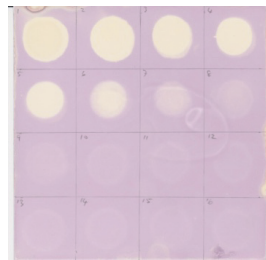

(12)

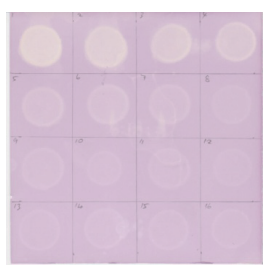

(1)

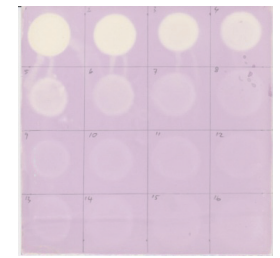

(7)

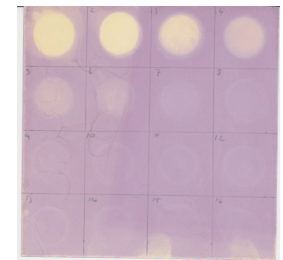

(13)

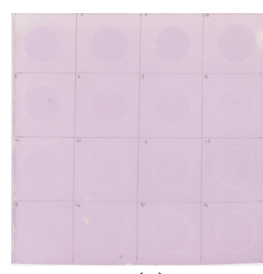

(2)

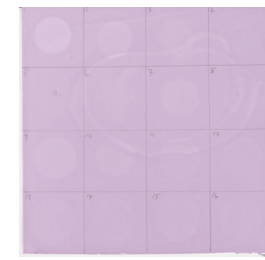

(8)

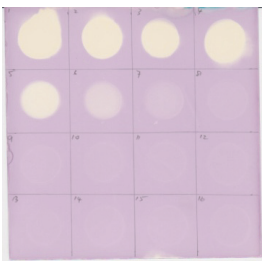

(14)

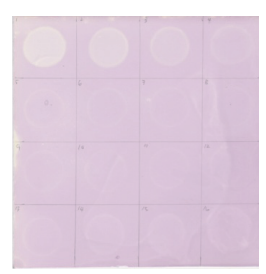

(3)

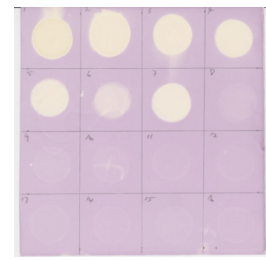

(9)

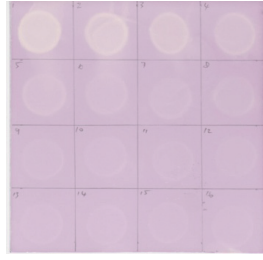

(4)

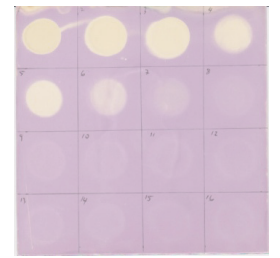

(10)

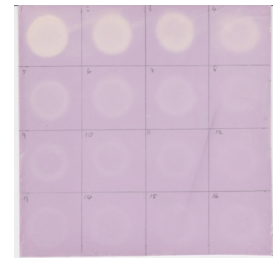

(5)

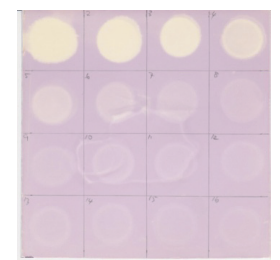

(11)

FIGURE 3: Rapid screening of radical scavenging activity by dot blot assay on a silica sheet stained with a DPPH solution in MeOH at 16 different concentrations, namely, $1000,500,250,125,62.5,31.25,15.63,7.81,3.91,1.95,0.97,0.488,0.244,0.122,0.06$, and $0.03 \mu \mathrm{g} / \mathrm{mL}$ applied from top to down. (A.A) ascorbic acid (positive control), (1) wogonin, (2) methyl ether (wogonin), (3) acetate (wogonin), (4) techtochrysin, (5) 8-hydroxy-7-methoxyflavone, (6) chrysin, (7) norwogonin, (8) acetate (norwogonin), (9) isoscutellarein, (10) hypolaetin, (11) kaempferol, (12) quercetin, (13) (+)-catechin, and (14) (-)-epicatechin.

the purple background as compared to the positive control, namely, ascorbic acid (Figure 3).

According to the color intensities, the overall order of the decreasing radical scavenging activity was found to be in the order of isoscutellarein $>$ quercetin $>$ hypolaetin $>$ kaempferol $>(-)$-epicatechin $>(+)$-catechin $>$ norwogonin $>$ chrysin $>$ wogonin $>$ techtochrysin $>8$-hydroxy-7methoxyflavone. The result corresponded to the result of $\mathrm{DPPH}$ radical scavenging assay.

3.3. DPPH Radical Scavenging Assay. DPPH is a stable free radical that can accept an electron or hydrogen radical to become a stable diamagnetic molecule. DPPH radical reacts with suitable reducing agent producing new bond, thus changing the color of the solution. The solution loses color with the increased concentration of antioxidant as the electrons are taken up by DPPH radical from the antioxidant which can be monitored spectrophotometrically by decrease in absorbance at $517 \mathrm{~nm}$ [23]. Results in Table 1 demonstrate that hypolaetin expressed the lowest value of IC $_{50}(3.69 \pm 0.11 \mu \mathrm{g} / \mathrm{mL})$, statistically similar to positive control, ascorbic acid $(4.75 \pm 0.91 \mu \mathrm{g} / \mathrm{mL})$, followed by isoscutellarein, quercetin, (-)-epicatechin, kaempferol, (+)catechin, norwogonin, and 8-hydroxy-7-methoxyflavone at $5.23 \pm 0.53,7.76 \pm 0.99,9.92 \pm 0.33,10.89 \pm 0.86,14.34 \pm 1.55$, $35.61 \pm 1.68$, and $68.24 \pm 3.70 \mu \mathrm{g} / \mathrm{mL}$, respectively, while the rest showed weak activity whereby the $\mathrm{IC}_{50}$ was found to be above $100 \mu \mathrm{g} / \mathrm{ml}$. These results further corroborate and explain the weak spots of rapid screening dot blot of DPPH staining for the same compounds.

3.4. ABTS $^{+}$Radical Scavenging Assay. This assay was based on the ability of the flavonoids to scavenge $\mathrm{ABTS}^{+}$radical. Using this method, the obtained result is presented in Table 1. Contrary to DPPH method, (+)-catechin and (-)-epicatechin showed the highest $\mathrm{ABTS}^{+}$radical scavenging activity $(0.62 \pm$ 0.05 and $0.70 \pm 0.08 \mu \mathrm{g} / \mathrm{mL}$ ) which is statistically significant as compared to positive control, trolox $(1.76 \pm 0.15)$, followed by hypolaetin, quercetin, norwogonin, kaempferol, isoscutellarein, 8-hydroxy-7-methoxyflavone, techtochrysin, and wogonin at $0.80 \pm 0.03,0.83 \pm 0.01,1.24 \pm 0.19,1.36 \pm$ $0.22,1.73 \pm 0.06,3.19 \pm 0.05,45.59 \pm 4.75$, and $52.65 \pm$ $2.99 \mu \mathrm{g} / \mathrm{mL}$, respectively. The rest showed $\mathrm{ABTS}^{+}$radical scavenging activity $>100 \mu \mathrm{g} / \mathrm{mL}$.

3.5. Xanthine Oxidase Inhibition (XOI) Assay. Xanthine oxidase $(\mathrm{XO})$, the key enzyme that catalyzes the final step in the conversion of purines to uric acid, thus plays a vital role in producing hyperuricemia which eventually leads to the gout inflammation [26, 27]. The xanthine oxidase inhibition activity of 14 flavonoids was tested via in vitro technique assay of xanthine oxidase. The validity of the method can be observed from the $\mathrm{IC}_{50}$ result of the positive control used, namely, allopurinol, which showed the highest inhibition 
TABLE 1: $\mathrm{IC}_{50}$ values of flavonoids for DPPH, $\mathrm{ABTS}^{+}$, and xanthine oxidase inhibition assays.

\begin{tabular}{|c|c|c|c|}
\hline Samples $(\mu \mathrm{g} / \mathrm{ml})$ & DPPH & $\mathrm{ABTS}^{+}$ & Xanthine oxidase \\
\hline Ascorbic acid & $4.75 \pm 0.91^{\mathrm{GHa}}$ & - & - \\
\hline Trolox & - & $1.76 \pm 0.15^{\mathrm{FG}}$ & - \\
\hline Allopurinol & - & - & $0.16 \pm 0.30^{\mathrm{D}}$ \\
\hline Wogonin & $>100^{\mathrm{B}}$ & $52.63 \pm 2.99^{\mathrm{D}}$ & NA \\
\hline Methyl ether (wogonin) & $>200^{\mathrm{A}}$ & $>200^{\mathrm{A}}$ & NA \\
\hline Acetate (wogonin) & $>200^{\mathrm{A}}$ & $>200^{\mathrm{A}}$ & NA \\
\hline Techtochrysin & $>100^{\mathrm{B}}$ & $45.59 \pm 4.75^{\mathrm{E}}$ & $>100^{\mathrm{A}}$ \\
\hline 8-Hydroxy-7-methoxyflavone & $68.24 \pm 3.70^{\mathrm{C}}$ & $3.19 \pm 0.15^{\mathrm{F}}$ & NA \\
\hline Chrysin & $>100^{\mathrm{B}}$ & $>100^{\mathrm{B}}$ & $>100^{\mathrm{A}}$ \\
\hline Norwogonin & $35.61 \pm 1.68^{\mathrm{D}}$ & $1.24 \pm 0.19^{\mathrm{FG}}$ & NA \\
\hline Acetate (norwogonin) & $>100^{\mathrm{B}}$ & $78.99 \pm 66.5^{\mathrm{C}}$ & NA \\
\hline Isoscutellarein & $5.23 \pm 0.53^{\mathrm{GHa}}$ & $1.73 \pm 0.06^{\mathrm{FG}}$ & $>100^{\mathrm{A}}$ \\
\hline Hypolaetin & $3.69 \pm 0.11^{\mathrm{Ha}}$ & $0.80 \pm 0.03^{\mathrm{FG}}$ & $>100^{\mathrm{A}}$ \\
\hline Kaempferol & $10.89 \pm 0.86^{\mathrm{EF}}$ & $1.36 \pm 0.22^{\mathrm{FG}}$ & $16.36 \pm 0.93^{\mathrm{B}}$ \\
\hline Quercetin & $7.76 \pm 0.99^{\mathrm{FG}}$ & $0.83 \pm 0.01^{\mathrm{FG}}$ & $8.58 \pm 0.72^{\mathrm{C}}$ \\
\hline$(+)$-Catechin & $14.34 \pm 1.55^{\mathrm{EF}}$ & $0.62 \pm 0.05^{\mathrm{G}}$ & NA \\
\hline (-)-Epicatechin & $9.92 \pm 0.33^{\mathrm{F}}$ & $0.70 \pm 0.08^{G}$ & NA \\
\hline
\end{tabular}

Values represent mean \pm SEM $(n=3)$, NA: not active; capital letters represent Tukey's test, small letters represent Dunnett's test, and means not sharing a letter are significantly different $(p<0.05)$.

at $0.163 \mu \mathrm{g} / \mathrm{mL}$ (Table 1). Among the 14 tested flavonoids, only kaempferol and quercetin showed high $50 \%$ of inhibition concentration $\left(\mathrm{IC}_{50}\right.$ ) of xanthine oxidase which was at $8.07 \mu \mathrm{g} / \mathrm{mL}$ and $16.36 \mu \mathrm{g} / \mathrm{mL}$, respectively. Isoscutellarein and chrysin showed low inhibition $(>100 \mu \mathrm{g} / \mathrm{mL})$ of xanthine oxidase while the others were found to be inactive.

3.6. Ferric Reducing Antioxidant Power (FRAP) Assay. The results were expressed quantitatively in terms of the ascorbic acid equivalent (AAE) $\mu \mathrm{g}$ of ascorbic acid/g. A standard curve of ascorbic acid was plotted. The data in Table 2 show that the kaempferol and isoscutellarein have the highest antioxidant capacity $(265.65 \pm 5.46$ and $262.91 \pm 4.99 \mathrm{AAE} \mu \mathrm{g}$ of ascorbic acid/g). This value was found to be more than twofold higher $(p<0.05)$ than AAE value of ascorbic acid (114.58 AAE $\mu \mathrm{g}$ of ascorbic acid/g). This was followed by hypolaetin, norwogonin, (-)-epicatechin, $(+)$-catechin, quercetin, and 8-hydroxy-7-methoxyflavone, with $262.91 \pm$ $4.99,177.37 \pm 1.82,152.14 \pm 7.30,152.07 \pm 1.95,148.12 \pm$ 4.40 , and $104.92 \pm 8.29$ of $\mathrm{AAE} \mu \mathrm{g}$ of ascorbic acid/g, respectively. Meanwhile, acetate of norwogonin, wogonin, chrysin, techtochrysin, acetate (wogonin), and methyl ether (wogonin) showed low ferric reducing antioxidant power with $39.63 \pm 1.01,39.15 \pm 1.68,21.38 \pm 1.86,11.49 \pm 0.32$, $5.06 \pm 3.24$, and $1.68 \pm 0.18$ of AAE $\mu \mathrm{g}$ of ascorbic acid/g, respectively.

3.7. $\alpha$-Glucosidase Inhibitory Assay. Tested on yeast $\alpha$ glycosidase, the reaction is initiated by reacting the inhibitor (sample) with the $\alpha$-glycosidase enzyme that competes with $\rho$-nitrophenol- $\rho$-D-glucopyranosidase for the binding site, thus releasing $\rho$-nitrophenol which was measured in the
TABLE 2: Result of FRAP in ascorbic acid equivalent (AAE).

\begin{tabular}{lc}
\hline Samples & FRAP $($ AAE $\mu \mathrm{g})$ \\
\hline Ascorbic acid & $114.58 \pm 0.27^{\mathrm{Da}}$ \\
(positive control) & $39.15 \pm 1.68^{\mathrm{E}}$ \\
Wogonin & $1.68 \pm 0.18^{\mathrm{G}}$ \\
Methyl-ether (wogonin) & $5.06 \pm 3.24^{\mathrm{G}}$ \\
Acetate (wogonin) & $11.49 \pm 0.32^{\mathrm{F}}$ \\
Techtochrysin & $104.92 \pm 8.29^{\mathrm{D}}$ \\
8-Hydroxy-7-methoxyflavone & $21.38 \pm 1.86^{\mathrm{F}}$ \\
Chrysin & $152.14 \pm 7.30^{\mathrm{C}}$ \\
Norwogonin & $39.63 \pm 1.01^{\mathrm{E}}$ \\
Acetate (norwogonin) & $262.91 \pm 4.99^{\mathrm{A}}$ \\
Isoscutellarein & $177.37 \pm 1.82^{\mathrm{B}}$ \\
Hypolaetin & $265.65 \pm 5.46^{\mathrm{A}}$ \\
Kaempferol & $138.93 \pm 6.22^{\mathrm{C}}$ \\
Quercetin & $148.12 \pm 4.40^{\mathrm{C}}$ \\
(+)-Catechin & $152.07 \pm 1.95^{\mathrm{C}}$ \\
(-)-Epicatechin &
\end{tabular}

Values represent mean $\pm \operatorname{SEM}(n=3)$, NA: not active; capital letters represent Tukey's test, small letters represent Dunnett's test, and means not sharing a letter are significantly different $(p<0.05)$.

assay. It is observed that quercetin showed statistically similar value of $\mathrm{IC}_{50}$ to positive control; meanwhile isoscutellarein and kaempferol showed significantly higher values of $\mathrm{IC}_{50}$ $(p<0.05)$ in inhibiting $\alpha$-glycosidase activity at $4.92 \pm$ $7.06,7.15 \pm 0.96$, and $12.19 \pm 4.63 \mu \mathrm{g} / \mathrm{ml}$, respectively. Meanwhile, hypolaetin showed a good inhibitory activity 
TABLE 3: $\mathrm{IC}_{50}$ values of flavonoids for $\alpha$-glucosidase and DPP-4 inhibition assays.

\begin{tabular}{|c|c|c|}
\hline Samples & $\alpha$-Glucosidase $(\mu \mathrm{g} / \mathrm{mg})$ & DPP-4 $(\mu \mathrm{g} / \mathrm{mg})$ \\
\hline Quercetin (commercial) & $4.30 \pm 1.06^{\mathrm{Ea}}$ & - \\
\hline Sitagliptin & - & $24.51 \pm 1.01^{\mathrm{Da}}$ \\
\hline Wogonin & $>100^{\mathrm{A}}$ & $>100^{\mathrm{A}}$ \\
\hline Methyl ether (wogonin) & NA & $>100^{\mathrm{A}}$ \\
\hline Acetate (wogonin) & $>100^{\mathrm{A}}$ & NA \\
\hline Techtochrysin & $>100^{\mathrm{A}}$ & $>100^{\mathrm{A}}$ \\
\hline 8-Hydroxy-7-methoxyflavone & $>100^{\mathrm{A}}$ & $>100^{\mathrm{A}}$ \\
\hline Chrysin & $>100^{\mathrm{A}}$ & NA \\
\hline Norwogonin & $>100^{\mathrm{A}}$ & $>100^{\mathrm{A}}$ \\
\hline Acetate (norwogonin) & NA & $>100^{\mathrm{A}}$ \\
\hline Isoscutellarein & $7.15 \pm 0.96^{\mathrm{D}}$ & $22.23 \pm 1.52^{\mathrm{Da}}$ \\
\hline Hypolaetin & $48.42 \pm 9.71^{\mathrm{B}}$ & $34.89 \pm 7.44^{\mathrm{B}}$ \\
\hline Kaempferol & $12.19 \pm 4.63^{\mathrm{C}}$ & $45.93 \pm 8.61^{\mathrm{B}}$ \\
\hline Quercetin & $4.92 \pm 7.06^{\mathrm{Ea}}$ & $21.75 \pm 5.81^{\mathrm{Da}}$ \\
\hline$(+)$-Catechin & NA & NA \\
\hline (-)-Epicatechin & NA & NA \\
\hline
\end{tabular}

Values represent mean \pm SEM $(n=3)$, NA: not active; capital letters represent significant difference based on Tukey's test $(p<0.05)$ and small letters represent significant difference based on Dunnett's test $(p<0.05)$.

at $48.42 \pm 9.71 \mu \mathrm{g} / \mathrm{ml}$. Wogonin, acetate of wogonin, techtochrysin, 8-hydroxy-7-methoxyflavone, chrysin, and norwogonin showed high value of $\mathrm{IC}_{50}(>100 \mu \mathrm{g} / \mathrm{ml})$ and the rest of the compounds were found to be inactive (Table 3 ).

3.8. Dipeptidyl Peptidase IV (DPP-4) Inhibitory Assay. For DPP-4 inhibitory assay, the reaction is based on the cleavage of the peptide bond by DPP releasing the free GlyPro-aminomethylcoumarin group, a fluorogenic substrate resulting in fluorescence excitation and emission. The result revealed that quercetin and isoscutellarein showed the highest $\mathrm{IC}_{50}$ value at $21.75 \pm 5.81$ and $22.23 \pm 1.52 \mu \mathrm{g} / \mathrm{ml}$ which is statistically similar to positive control, sitagliptin at $24.51 \pm 1.01$, followed by hypolaetin and kaempferol at $34.89 \pm 7.44$ and $45.93 \pm 8.61 \mu \mathrm{g} / \mathrm{ml}$, respectively. Meanwhile, wogonin, methyl ether (wogonin), techtochrysin, 8hydroxy-7-methoxyflavone, norwogonin, and acetate (norwogonin) showed weak inhibitory activity $(>100 \mu \mathrm{g} / \mathrm{ml})$, and the remaining compounds showed no activity (Table 3 ).

\section{Discussion}

This study has compared the bioactivities of 14 different compounds comprising three structural variations of flavonoids which are flavones (absence of hydroxyl group at position 3), flavonol (presence of hydroxyl group at position 3), and flavanol (absence of double bond and ketonic group at positions 2-3 and 4, resp.) (Figure 4).

The antioxidant and radical scavenging activities of the flavonoids tested have been shown in Tables 1 and 2 which could be attributed to the high reactivity of hydroxyl substituents. For instance, quercetin, hypolaetin, $(-)$-epicatechin, and (+)-catechin have five hydroxyl groups attached to them which make them potent antioxidant and radical scavengers. Table 4 depicts the chemical structures and substituents where the number and configuration of hydroxyl groups are connected to their bioactivity. However, increase of activity was also observed to depend on the configuration of hydroxylation rather than the number of hydroxyl groups. For example, for DPPH radical scavenging and FRAP assays, even though kaempferol and isoscutellarein have only four hydroxyl groups, the antioxidant capacity was shown higher than the (-)-epicatechin and (+)-catechin.

Most antioxidant studies on flavonoids have concluded that an ortho-dihydroxy (catechol) structure in B ring is important for high scavenging activity [4, 5, 41-43]. The B ring hydroxyl configuration in flavonoids has been reported to be the most significant determinant ROS scavenging because it donates hydrogen and an electron to hydroxyl, hydroperoxyl, and peroxynitrite radicals, stabilizing them and giving rise to a relatively stable flavonoids radical [44, 45]. It was also observed in this study that catechol substituent attached on $\mathrm{B}$ ring has imposed high activity on $\mathrm{DPPH}, \mathrm{ABTS}^{+}$radical scavenging, and FRAP antioxidant as demonstrated by quercetin, hypolaetin, isoscutellarein, (-)epicatechin, and (+)-catechin. The presence of the hydroxyl groups in ring A and catechol structure or $4^{\prime}$-hydroxyl group in ring $\mathrm{B}$ seems to enhance the antioxidant activity in these radical assays. Cao et al. [44] concluded that a catechol moiety on ring $\mathrm{B}$ is essential for a high scavenging activity and this activity is proportional to the number of hydroxyl groups. The hydroxyl substituents on radical scavenging activity are considered to be the source of hydrogen atom that neutralizes radical species [46].

Alkylation and acetylation of phenolic groups at positions C-5, C-7, and C-8 (i.e., methoxy or acetate groups) were 
TABLE 4: Chemical structures and substituents of selected flavonoids.

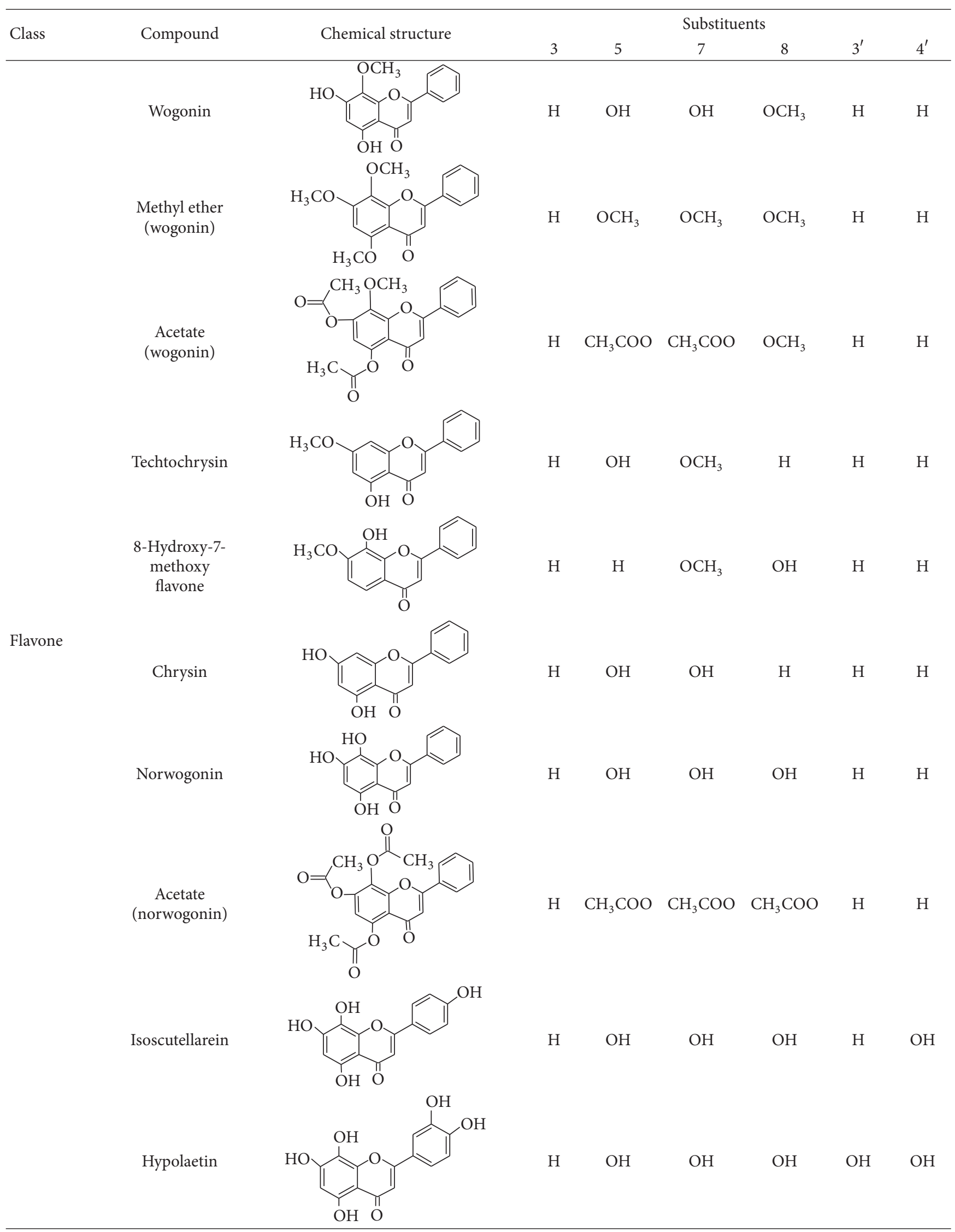


TABLE 4: Continued.

\begin{tabular}{|c|c|c|c|c|c|c|c|c|}
\hline \multirow{2}{*}{ Class } & \multirow{2}{*}{ Compound } & \multirow{2}{*}{ Chemical structure } & \multicolumn{6}{|c|}{ Substituents } \\
\hline & & & 3 & 5 & 7 & 8 & $3^{\prime}$ & $4^{\prime}$ \\
\hline \multirow{2}{*}{ Flavonol } & Kaempferol & & $\mathrm{OH}$ & $\mathrm{OH}$ & $\mathrm{OH}$ & $\mathrm{H}$ & $\mathrm{H}$ & $\mathrm{OH}$ \\
\hline & Quercetin & & $\mathrm{OH}$ & $\mathrm{OH}$ & $\mathrm{OH}$ & $\mathrm{H}$ & $\mathrm{OH}$ & $\mathrm{OH}$ \\
\hline \multirow{3}{*}{ Flavanol } & $\begin{array}{c}(+) \text {-Catechin } \\
(2 R, 3 S)\end{array}$ & & $\begin{array}{l}\beta- \\
\mathrm{OH}\end{array}$ & $\mathrm{OH}$ & $\mathrm{OH}$ & $\mathrm{H}$ & $\mathrm{OH}$ & $\mathrm{OH}$ \\
\hline & & & & & & & & \\
\hline & $\begin{array}{c}(-) \text {-Epicatechin } \\
(2 R, 3 R)\end{array}$ & & $\begin{array}{c}\alpha- \\
\mathrm{OH}\end{array}$ & $\mathrm{OH}$ & $\mathrm{OH}$ & $\mathrm{H}$ & $\mathrm{OH}$ & $\mathrm{OH}$ \\
\hline
\end{tabular}<smiles>O=c1cc(-c2ccccc2)oc2ccccc12</smiles><smiles>O=c1c(O)c(-c2ccccc2)oc2ccccc12</smiles><smiles>OC1Cc2ccccc2OC1c1ccccc1</smiles>

FIGURE 4: Structure of the different classes of flavonoids.

found to decrease the antioxidant and scavenging activities as observed from the result of DPPH radical scavenging assay, FRAP assay, and xanthine oxidase inhibitory assay of semisynthesized wogonin and norwogonin analogs. Studies showed that replacing the active hydroxyl groups by one or more methoxy groups significantly decreased the activity [41-43]. Moreover, in ABTS+ radical scavenging assay, methoxy group seemed to show minimal effect to support antioxidant activity as shown by wogonin, techtochrysin, and 8-hydroxy-7-methoxyflavone. All these three flavonoids have methoxy groups attached to positions C-8 and C-7, respectively, which showed minimal role of bioactivity which was also supported by the study carried out by Jang et al. [47].

For xanthine oxidase inhibitory assay, among different classes of flavonoids, only flavonol (quercetin and kaempferol) expressed significant xanthine oxidase inhibitory effect. Meanwhile, isoscutellarein, hypolaetin, chrysin, and techtochrysin were seen to demonstrate low xanthine oxidase inhibitory activity (Table 2 ). This observation further illustrates the importance of the C-3 hydroxyl group, C-2C-3 double bond, and ketone group at C-4 with regard to exerting the inhibitory effect against xanthine oxidase. $(+)$ Catechin and (-)-epicatechin were shown to be inactive even though both compounds exhibited strong DPPH, $\mathrm{ABTS}^{+}$ radical scavenging activities and FRAP assay activity, which means catechol structure of $\mathrm{B}$ ring, which gives antioxidative potential to flavonoids, was not related to xanthine oxidase inhibition [5]. Comparing the inhibition of xanthine oxidase with that of flavanol and flavonol groups, it can be observed that the presence of hydroxyl group at C-3 and absence of 4-ketonic group and C-2-C-3 double bond reduced the xanthine oxidase inhibitory effect. Additionally, with a double bond between $\mathrm{C}-2$ and $\mathrm{C}-3$, ring $\mathrm{B}$ will be coplanar with rings $\mathrm{A}$ and $\mathrm{C}$ due to the conjugation. The saturation of this double bond will annihilate its conjugation and planarity. This implies that a planar flavonoids structure such as flavone 
structure is essential for xanthine oxidase inhibition as the same observation was also supported by several studies [5, 45-47].

One of the therapeutic approaches to managing diabetes mellitus is to retard the absorption of glucose via inhibition of digestive enzymes in the digestive organs such as the $\alpha$-glucosidase [48, 49] and $\alpha$-amylase [50]. During the last 20 years, naturally occurring flavonoids and synthetic analogs have been extensively studied as $\alpha$-glucosidase inhibitors [51]. $\alpha$-Glucosidase is a membrane bound enzyme located at the epithelium of the small intestine that catalyzes the cleavage of glucose from disaccharides to monosaccharides [52]. Inhibitors of $\alpha$-glucosidase are used to control the blood sugar levels for type 2 diabetes mellitus. Usually, $\alpha$-glucosidase inhibitors are consumed with meals as they act to decelerate the breakdown of complex sugars into glucose resulting in a delay in glucose absorption which lowers postprandial blood sugar levels [53]. This study demonstrated that quercetin from flavonol group has the highest $\mathrm{IC}_{50}$ value as compared to other flavanoids. A study by $\mathrm{Xu}$ [54] has reported that dihydroxyl groups at positions C- $3^{\prime}$ and C- $4^{\prime}$ (catechol) of flavonoids are effectively conjugated with the active-site residues of $\alpha$-glucosidase. Existence of catechol system on the B ring of flavonoids is expected to contribute to the distribution of electron cloud which then becomes accessible to donate hydrogen atoms to form hydrogen bonds with active-site residues of $\alpha$-glucosidase, thereby playing a crucial role in inhibiting its action [55]. However, isoscutellarein and kaempferol have only one hydroxyl group attached on the B ring at C- $4^{\prime}$ position as compared to quercetin (Table 4). Due to lack of essential catechol system in both isoscutellarein and kaempferol, the electron cloud density of B ring could be slightly decreased, which may be responsible for less interaction with the binding sites of $\alpha$-glucosidase residues and, therefore, they are expected to exert less inhibitory action; consequently, both compounds exhibited slightly less potent $\alpha$-glucosidase inhibitory activity compared to quercetin. Owing to its potent digestive enzymes inhibitory action, quercetin has been recently recognised as positive control in many in vitro antidiabetic studies using $\alpha$ glucosidase as one of the subjects to determine antidiabetic activity for natural as well as synthetic compounds [52]. In addition to that, kaempferol and isoscutellarein have also been reported as promising $\alpha$-glucosidase inhibitors due to their potent $\alpha$-glucosidase inhibitory activity $[56,57]$.

Dipeptidyl peptidase IV (DPP-4) inhibitors are one of the newest therapeutic agents against type 2 diabetes mellitus [58-61]. DPP-4 is a serine exopeptidase hormone, known to degrade two major gut incretin hormones that stimulate insulin release, that is, glucagon-like peptide-1 (GLP-1) and glucose-dependent insulinotropic polypeptide (GIP), leading to a very short half-life (approximately $2 \mathrm{~min}$ ) of the hormones [58-61]. Inhibition of DPP-4 will prolong the halflife of GLP-1 and GIP hormones, resulting in the elevation of plasma insulin levels in human body. Result showed that quercetin from the flavonol group revealed the highest $\mathrm{IC}_{50}$ to inhibit DPP-4 activity, followed by isoscutellarein and hypolaetin from the flavone group. Moreover, kaempferol from the flavonol group also showed good inhibitory activity of DPP-4. These results have further highlighted the importance of hydroxyl group's presence in expressing bioactivity of flavonoids which are in line with the results from Fan et al. study [62]. Quercetin and hypolaetin have five hydroxyl groups; meanwhile isoscutellarein and kaempferol have four hydroxyl groups attached to rings $\mathrm{A}, \mathrm{B}$, and $\mathrm{C}$, respectively. Additionally, the configuration of hydroxyl groups also plays an important role and the catechol/hydroxyl group attached on $\mathrm{B}$ ring has been found to enhance $\alpha$-glucosidase and DPP-4 inhibitory activities. Moreover, lack of C-2-C-3 double bond and ketonic group at C-4 appeared to lower the inhibitory activity for both the $\alpha$-glucosidase and DPP-4 antidiabetic effects.

To summarize, results of antioxidant and antidiabetic assays have shown that the chemical criterion is fundamental for the bioactivity of these polyphenolic compounds (Figure 5). The spatial arrangement and alkyl substitution are the remarkable determinants of antioxidant and antidiabetic activities compared to the flavan backbone alone. Also, both configuration and the total number of hydroxyl groups substantially influence the mechanisms of radical scavenging [63] and antidiabetic effects. Thus, the total of hydroxyl groups, hydroxyl configuration, C-2-C-3 double bond, and C-4 ketonic functional group are the essential features in the manifestation of bioactivity of flavonoids especially for antidiabetic effect.

\section{Conclusion}

The radical derivatives of oxygen (ROS) are the most important free radical in biological systems and harmful byproducts generated during normal cellular functions. Increasing intake of natural antioxidants may help to maintain a tolerable antioxidant status, thus preventing the oxidative stress that could lead to pathogenesis of diabetes mellitus. Flavonoids are one of the most important groups of bioactive compounds among secondary metabolites. We have reported in vitro antioxidant and antidiabetic activities of some selected flavonoids. This study has further revealed that the total number and configuration of hydroxyl groups existing on the compounds increased the antioxidant and antidiabetic effects of flavonoids. The absence of C-2-C-3 double bond as well as ketonic group at $\mathrm{C}-4$ in ring $\mathrm{C}$ reduced the xanthine oxidase, $\alpha$-glucosidase, and DPP-4 inhibitory activities. It was also discovered that the presence of catechol system on the ring $B$ is not significant enough without the presence of C-2-C-3 double bond and ketonic group at C-4 position for the manifestation of antioxidant and antidiabetic effects. Moreover, alkylation or acetylation of hydroxyl groups on ring A decreased the bioactivity of flavonoids revealing their incapability of interacting with the binding sites of enzymes as well as quenching ROS. The results should be encouraged in future in vivo studies, which could ultimately lead to the development of nutritional product and semisynthetic analogs that retain substantial antidiabetic capacity with minimal adverse effects. 


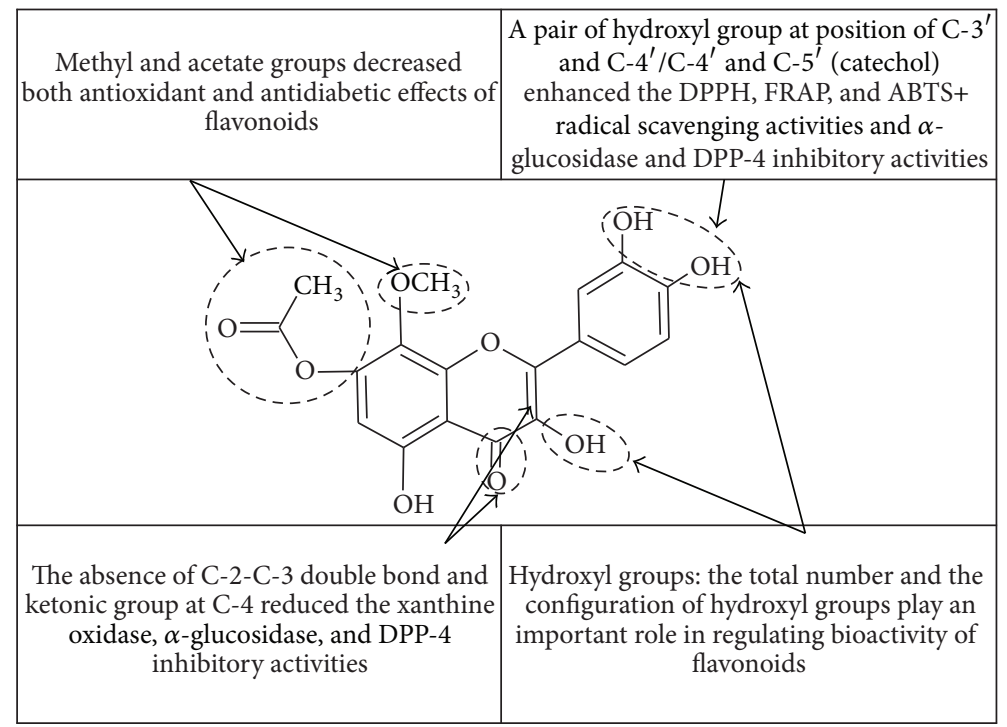

FIGURE 5: Summary of SAR study of antioxidant and antidiabetic effects of flavonoids.

\section{Conflicts of Interest}

The authors declare that there are no conflicts of interest.

\section{Acknowledgments}

The authors are extremely indebted to the Ministry of Higher Education (MOHE), Malaysia, and the Research Management Center, IIUM, for providing financial assistance through Fundamental Grant Research Scheme (FRGS 13089-0330) and Research Initiative Grant Schemes (RIGS 16-294-0458), respectively, to accomplish this work. The authors would also like to thank the Molecular Structure Determination Laboratory (MSDL), Centre for Research and Instrumentation Management, Universiti Kebangsaan Malaysia (CRIM, UKM), for running NMR spectra under the mentorship of Associate Professor Dr. Jalifah Latip. Lastly, the authors would like to express their gratitude to Universiti Kebangsaan Malaysia for their additional financial support under the DIP-2015-015 research grant.

\section{References}

[1] J. Wall, "Antioxidants in prevention of reperfusion damage vascular endothelium," The Trinity Student Medical Journal, vol. 1, pp. 67-71, 2000.

[2] D. Amic, D. Davidovic-Amic, D. Beslo, and N. Trinajstic, "Structureradical scavenging activity relationships of flavonoids," Croatia ChemicaActa, vol. 76, pp. 55-61, 2003.

[3] M. A. Soobrattee, V. S. Neergheen, A. Luximon-Ramma, O. I. Aruoma, and T. Bahorun, "Phenolics as potential antioxidant therapeutic agents: Mechanism and actions," Mutation Research - Fundamental and Molecular Mechanisms of Mutagenesis, vol. 579, no. 1-2, pp. 200-213, 2005.

[4] Y. Hanasaki, S. Ogawa, and S. Fukui, "The correlation between active oxygens scavenging and antioxidative effects of flavonoids," Free Radical Biology \& Medicine, vol. 16, no. 6, pp. 845-850, 1994.

[5] P. Cos, L. Ying, M. Calomme et al., "Structure-activity relationship and classification of flavonoids as inhibitors of xanthine oxidase and superoxide scavengers," Journal of Natural Products, vol. 61, no. 1, pp. 71-76, 1998.

[6] I. Morel, G. Lescoat, P. Cogrel et al., "Antioxidant and ironchelating activities of the flavonoids catechin, quercetin and diosmetin on iron-loaded rat hepatocyte cultures," Biochemical Pharmacology, vol. 45, no. 1, pp. 13-19, 1993.

[7] R. Hirano, W. Sasamoto, A. Matsumoto, H. Itakura, O. Igarashi, and K. Kondo, "Antioxidant ability of various flavonoids against DPPH radicals and LDL oxidation," Journal of Nutritional Science and Vitaminology, vol. 47, no. 5, pp. 357-362, 2001.

[8] C. C. Lima, R. P. Lemos, and L. M. Conserva, "Dilleniaceae family: an overview of its ethnomedicinal uses, biological and phytochemical profile," Journal of Pharmacognosy and Phytochemistry, vol. 3, no. 2, pp. 181-204, 2014.

[9] J. S. Johansen, A. K. Harris, D. J. Rychly, and A. Ergul, “Oxidative stress and the use of antioxidants in diabetes: linking basic science to clinical pratice," Cardiovascular Diabetology, vol. 4, article 5, 2005.

[10] P. Rosen, P. P. Nawroth, G. King, W. Möller, H. J. Tritschler, and L. Packer, "The role of oxidative stress in the onset and progression of diabetes and its complications: a summary of a congress series sponsored by UNESCO-MCBN, the American diabetes association and the German diabetes society," Diabetes/Metabolism Research and Reviews, vol. 17, no. 3, pp. 189212, 2001.

[11] F. Folli, D. Corradi, P. Fanti et al., "The role of oxidative stress in the pathogenesis of type 2 diabetes mellitus micro-and macrovascular complications: Avenues for a mechanistic-based therapeutic approach," Current Diabetes Reviews, vol. 7, no. 5, pp. 313-324, 2011.

[12] B. Halliwell and J. M. C. Gutteridge, "Role of free radicals and catalytic metal ions in human disease: an overview," Methods in Enzymology, vol. 186, pp. 1-85, 1990.

[13] A. Ceriello, "Oxidative stress and glycemic regulation," Metabolism - Clinical and Experimental, vol. 49, no. 2, pp. 27-29, 2000. 
[14] G. Paolisso, A. D’Amore, V. V. Balbi et al., "Plasma vitamin C affects glucose homeostasis in healthy subjects and non-insulindependent diabetics," American Journal of Physiology, vol. 1266, pp. 261-268, 1994.

[15] G. Paolisso, A. D’Amore, D. Giugliano, A. Ceriello, M. Varricchio, and F. D'Onofrio, "Pharmacologic doses of vitamin E improve insulin action in healthy subjects and non-insulindependent diabetic patients," American Journal of Clinical Nutrition, vol. 57, no. 5, pp. 650-656, 1993.

[16] P. Faure, E. Rossini, J. L. Lafond, M. J. Richard, A. Favier, and S. Halimi, "Vitamin E improves the free radical defense system potential and insulin sensitivity of rats fed high fructose diets," Journal of Nutrition, vol. 127, no. 1, pp. 103-107, 1997.

[17] E. Nicolle, F. Souard, P. Faure, and A. Boumendjel, "Flavonoids as promising lead compounds in type 2 diabetes mellitus: molecules of interest and structure-activity relationship," Current Medicinal Chemistry, vol. 18, no. 17, pp. 2661-2672, 2011.

[18] P. Bansal, P. Paul, J. Mudgal et al., "Antidiabetic, antihyperlipidemic and antioxidant effects of the flavonoid rich fraction of Pilea microphylla (L.) in high fat diet/streptozotocin-induced diabetes in mice," Experimental and Toxicologic Pathology, vol. 64, no. 6, pp. 651-658, 2012.

[19] M. Aslan, D. Deliorman Orhan, N. Orhan, E. Sezik, and E. Yesilada, "In vivo antidiabetic and antioxidant potential of Helichrysum plicatum ssp. plicatum capitulums in streptozotocin-induced-diabetic rats," Journal of Ethnopharmacology, vol. 109, no. 1, pp. 54-59, 2007.

[20] P. Sarkhail, S. Rahmanipour, S. Fadyevatan et al., "Antidiabetic effect of Phlomis anisodonta: effects on hepatic cells lipid peroxidation and antioxidant enzymes in experimental diabetes," Pharmacological Research, vol. 56, no. 3, pp. 261-266, 2007.

[21] K. Muhammad, S. M. Mohd, A. Muhammad, H. Sardar, and U. Izhar, "A review on Malaysian medicinal plants having antihyperglycemic activity," Journal of Coastal Life Medicine, vol. 4, no. 11, pp. 898-901, 2016.

[22] F. Abdullah, F. Jamaludin, N. H. Ismail, K. M. Khan, and S. N. Mohd Hashim, "Xanthine Oxidase Inhibitory Activity of," The Open Conference Proceedings Journal, vol. 4, no. 1, pp. 168-168, 2013.

[23] Q. U. Ahmed, B. B. S. Dogarai, M. Z. A. M Amiroudine et al., "Antidiabetic activity of the leaves of Tetraceraindica Merr. (Dilleniaceae) in vivo and in vitro," Journal of Medicinal Plants Research, vol. 6, no. 49, pp. 5912-5922, 2012.

[24] Q. U. Ahmed, A. Umar, M. Z. A. M. Amiroudine, M. Taher, D. Susanti, and J. Latip, "Phytochemical investigation of the leaves of Tetracerascandens Linn. and antidiabetic activity of hypoletin," in Proceedings of the International Conference on Science, Technology and Social Sciences (ICSTSS, Springer Science, pp. 591-608, 2014.

[25] T. Mabry, K. R. Markham, and M. B. Thomas, The systematic identification of flavonoids, Springer Science \& Business Media, 2012.

[26] C. Soler-Rivas, J. C. Espín, and H. J. Wichers, "An easy and fast test to compare total free radical scavenger capacity of foodstuffs," Phytochemical Analysis, vol. 11, no. 5, pp. 330-338, 2000.

[27] L. L. Mensor, F. S. Menezes, G. G. Leitao et al., "Screening of Brazilian plant extracts for antioxidant activity by the use of DPPH free radical method," Phytotherapy Research, vol. 15, pp. 127-130, 2001.

[28] B. Fauconneau, P. Waffo-Teguo, F. Huguet, L. Barrier, A. Decendit, and J.-M. Merillon, "Comparative study of radical scavenger and antioxidant properties of phenolic compounds from Vitis vinifera cell cultures using in vitro tests," Life Sciences, vol. 61, no. 21, pp. 2103-2110, 1997.

[29] R. Re, N. Pellegrini, A. Proteggente, A. Pannala, M. Yang, and C. Rice-Evans, "Antioxidant activity applying an improved ABTS radical cation decolorization assay," Free Radical Biology \& Medicine, vol. 26, no. 9-10, pp. 1231-1237, 1999.

[30] W.-S. Chang, Y.-H. Chang, F.-J. Lu, and H.-C. Chiang, "Inhibitory effects of phenolics on xanthine oxidase," Anticancer Reseach, vol. 14, no. 2, pp. 501-506, 1994.

[31] L.-N. Huo, W. Wang, C.-Y. Zhang et al., "Bioassay-guided isolation and identification of xanthine oxidase inhibitory constituents from the leaves of perilla frutescens," Molecules, vol. 20, no. 10, pp. 17848-17859, 2015.

[32] M. T. T. Nguyen, S. Awale, Y. Tezuka, Q. L. Tran, H. Watanabe, and S. Kadota, "Xanthine oxidase inhibitory activity of Vietnamese medicinal plants," Biological \& Pharmaceutical Bulletin, vol. 27, no. 9, pp. 1414-1421, 2004.

[33] A. Abdullahi, R. Hamzah, A. Jigam et al., "Inhibitory activity of xanthine oxidase by fractions Crateva adansonii," Journal of Acute Disease, vol. 1, no. 2, pp. 126-129, 2012.

[34] A. Szydlowska-Czerniak, K. Trokowski, G. Karlovits, and E. Szłyk, "Effect of refining processes on antioxidant capacity, total contents of phenolics and carotenoids in palm oils," Food Chemistry, vol. 129, no. 3, pp. 1187-1192, 2011.

[35] A. Khatib, V. Perumal, Q. Ahmed, B. Uzir, and S. Murugesu, "Low inhibition of alpha-glucosidase and xanthine oxidase activities of ethanol extract of Momordica charantia fruit," Journal of Pharmaceutical Negative Results, vol. 8, no. 1, p. 20, 2017.

[36] L. J. Harrison, G.-L. Sia, and K.-Y. Sim, "5,7-Dihydroxy-8methoxyflavone from Tetracera indica," Planta Medica, vol. 60, no. 5, pp. 493-494, 1994.

[37] A. A. L. Mesquita, D. D. B. Corrêa, A. P. De Pádua, M. L. O. Guedes, and O. R. Gottlieb, "Flavonoids from four compositae species," Phytochemistry, vol. 25, no. 5, pp. 1255-1256, 1986.

[38] T. Supinya, S. Sanan, and K. Sopa, "Anti-allergic activity of compounds from Kaempferia parviflora," Journal of Ethnopharmacology, vol. 116, pp. 191-193, 2008.

[39] P. Seetharaman, S. Gnanasekar, R. Chandrasekaran, G. Chandrakasan, M. Kadarkarai, and S. Sivaperumal, "Isolation and characterization of anticancer flavone chrysin (5,7-dihydroxy flavone)-producing endophytic fungi from Passiflora incarnata L. leaves," Annals of Microbiology, vol. 67, no. 4, pp. 321-331, 2017.

[40] Y. Miyasaki, J. D. Rabenstein, J. Rhea et al., "Isolation and characterization of antimicrobial compounds in plant extracts against multidrug-resistant Acinetobacter baumannii," PLoS ONE, vol. 8, no. 4, Article ID e61594, 2013.

[41] J. Baumann, G. Wurm, and F. Von Bruchhausen, "Prostaglandin synthetase inhibition by flavonoids and phenolic compounds in relation to their $\mathrm{O}_{2}$-scavenging properties (author's transl)," Archiv der Pharmazie, vol. 313, no. 4, p. 330, 1980.

[42] A. I. Huguet, S. Máñez, and M. J. Alcaraz, "Superoxide scavenging properties of flavonoids in a non-enzymic system," ZeitschriftfürNaturforschung C, vol. 45, no. 1-2, pp. 19-24, 1990.

[43] N. Cotelle, J. L. Bernier, J. P. Hénichart, J. P. Catteau, E. Gaydou, and J. C. Wallet, "Scavenger and antioxidant properties of ten synthetic flavones," Free Radical Biology \& Medicine, vol. 13, no. 3, pp. 211-219, 1992.

[44] G. Cao, E. Sofic, and R. L. Prior, "Antioxidant and prooxidant behavior of flavonoids: structure-activity relationships," Free Radical Biology \& Medicine, vol. 22, no. 5, pp. 749-760, 1997. 
[45] K. E. Heim, A. R. Tagliaferro, and D. J. Bobilya, "Flavonoid antioxidants: chemistry, metabolism and structure-activity relationships," The Journal of Nutritional Biochemistry, vol. 13, no. 10, pp. 572-584, 2002.

[46] A. Seyoum, K. Asres, and F. K. El-Fiky, "Structure-radical scavenging activity relationships of flavonoids," Phytochemistry, vol. 67, no. 18, pp. 2058-2070, 2006.

[47] J. Jang, H. P. Kim, and H. Park, "Structure and antiinflammatory activity relationships of wogonin derivatives," Archives of Pharmacal Research, vol. 28, no. 8, pp. 877-884, 2005.

[48] C. Rosak and G. Mertes, "Effects of acarbose on proinsulin and insulin secretion and their potential significance for the intermediary metabolism and cardiovascular system," Current Diabetes Reviews, vol. 5, no. 3, pp. 157-164, 2009.

[49] T. Nishioka, J. Kawabata, and Y. Aoyama, "Baicalein, an $\alpha$ glucosidase inhibitor from Scutellaria baicalensis," Journal of Natural Products, vol. 61, no. 11, pp. 1413-1415, 1998.

[50] K. Tadera, Y. Minami, K. Takamatsu, and T. Matsuoka, "Inhibition of $\alpha$-glucosidase and $\alpha$-amylase by flavonoids," Journal of Nutritional Science and Vitaminology, vol. 52, no. 2, pp. 149-153, 2006.

[51] Y. Zhenhua, Z. Wei, F. Fajin, Z. Yong, and K. Wenyi, " $\alpha$ Glucosidase inhibitors isolated from medicinal plants," Journal of Food Science and Human Wellness, vol. 3, no. 3, pp. 136-174, 2014.

[52] N. F. Brás, N. M. F. Cerqueira, M. J. Ramos, and P. A. Fernandes, "Glycosidase inhibitors: a patent review (2008-2013)," Expert Opinion on Therapeutic Patents, vol. 24, no. 8, pp. 857-874, 2014.

[53] Y. Q. Li, F. C. Zhou, F. Gao, J. S. Bian, and F. Shan, "Comparative evaluation of quercetin, isoquercetin and rutin as inhibitors of $\alpha$-glucosidase," Journal of Agricultural and Food Chemistry, vol. 57, no. 24, pp. 11463-11468, 2009.

[54] H. Xu, "Inhibition kinetics of flavonoids on yeast $\alpha$-glucosidase merged with docking simulations," Protein and Peptide Letters, vol. 17, no. 10, pp. 1270-1279, 2010.

[55] J. Vaya, S. Mahmood, A. Goldblum et al., "Inhibition of LDL oxidation by flavonoids in relation to their structure and calculated enthalpy," Phytochemistry, vol. 62, no. 1, pp. 89-99, 2003.

[56] X. Peng, G. Zhang, Y. Liao, and D. Gong, "Inhibitory kinetics and mechanism of kaempferol on $\alpha$-glucosidase," Food Chemistry, vol. 190, pp. 207-215, 2016.

[57] J. Kawabata, K. Mizuhata, E. Sato, T. Nishioka, Y. Aoyama, and T. Kasai, "6-Hydroxyflavonoids as $\alpha$-glucosidase inhibitors from marjoram (origanum majorana) leaves," Bioscience, Biotechnology, and Biochemistry, vol. 67, no. 2, pp. 445-447, 2003.

[58] R. Mentlein, "Dipeptidyl-peptidase IV (CD26)-role in the inactivation of regulatory peptides," Regulatory Peptides, vol. 85, no. 1, pp. 9-24, 1999.

[59] C. F. Deacon, M. A. Nauck, J. Meier, K. Hücking, and J. J. Holst, "Degradation of endogenous and exogenous gastric inhibitory polypeptide in healthy and in type 2 diabetic subjects as revealed using a new assay for the intact peptide," The Journal of Clinical Endocrinology \& Metabolism, vol. 85, no. 10, pp. 3575-3581, 2000.

[60] E. P. Semighini, J. A. Resende, P. De Andrade et al., "Using computer-aided drug design and medicinal chemistry strategies in the fight against diabetes," Journal of Biomolecular Structure and Dynamics, vol. 28, no. 5, pp. 787-796, 2011.
[61] P. Jadav, R. Bahekar, S. R. Shah et al., "Long-acting peptidomimetics based DPP-IV inhibitors," Bioorganic \& Medicinal Chemistry Letters, vol. 22, no. 10, pp. 3516-3521, 2012.

[62] J. Fan, M. H. Johnson, M. A. Lila, G. Yousef, and E. G. De Mejia, "Berry and citrus phenolic compounds inhibit dipeptidyl peptidase IV: Implications in diabetes management," EvidenceBased Complementary and Alternative Medicine, vol. 2013, Article ID 479505, 2013.

[63] P. L. Teissedre, E. N. Frankel, A. L. Waterhouse, H. Peleg, and J. Bruce German, "Inhibition of in vitro human LDL oxidation by phenolic antioxidants from grapes and wines," Journal of the Science of Food and Agriculture, vol. 70, no. 1, pp. 55-61, 1996. 

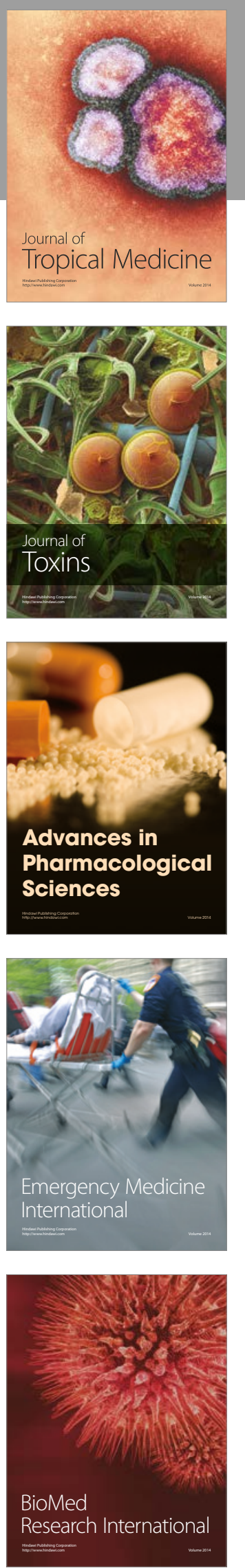
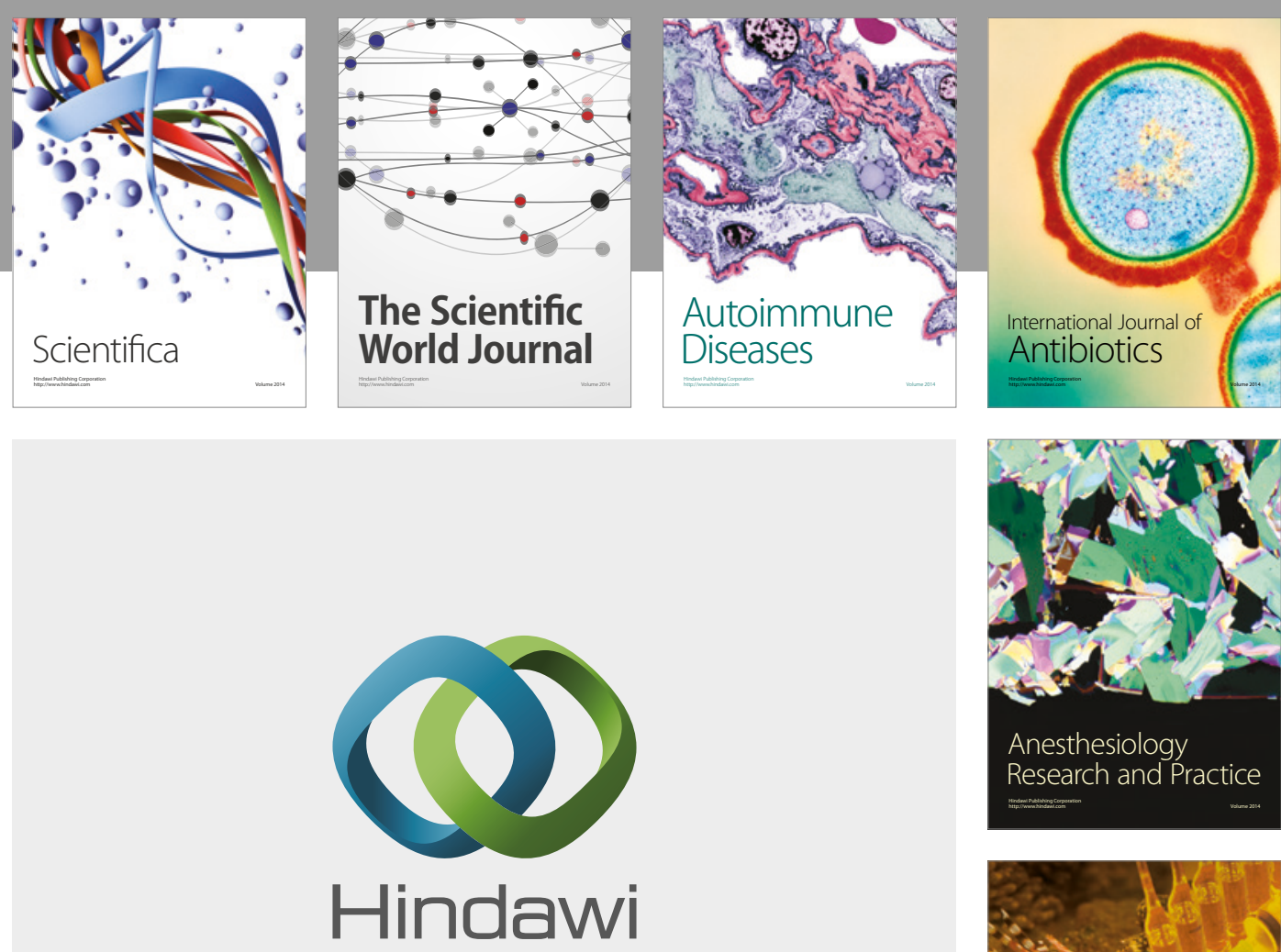

Submit your manuscripts at

https://www.hindawi.com
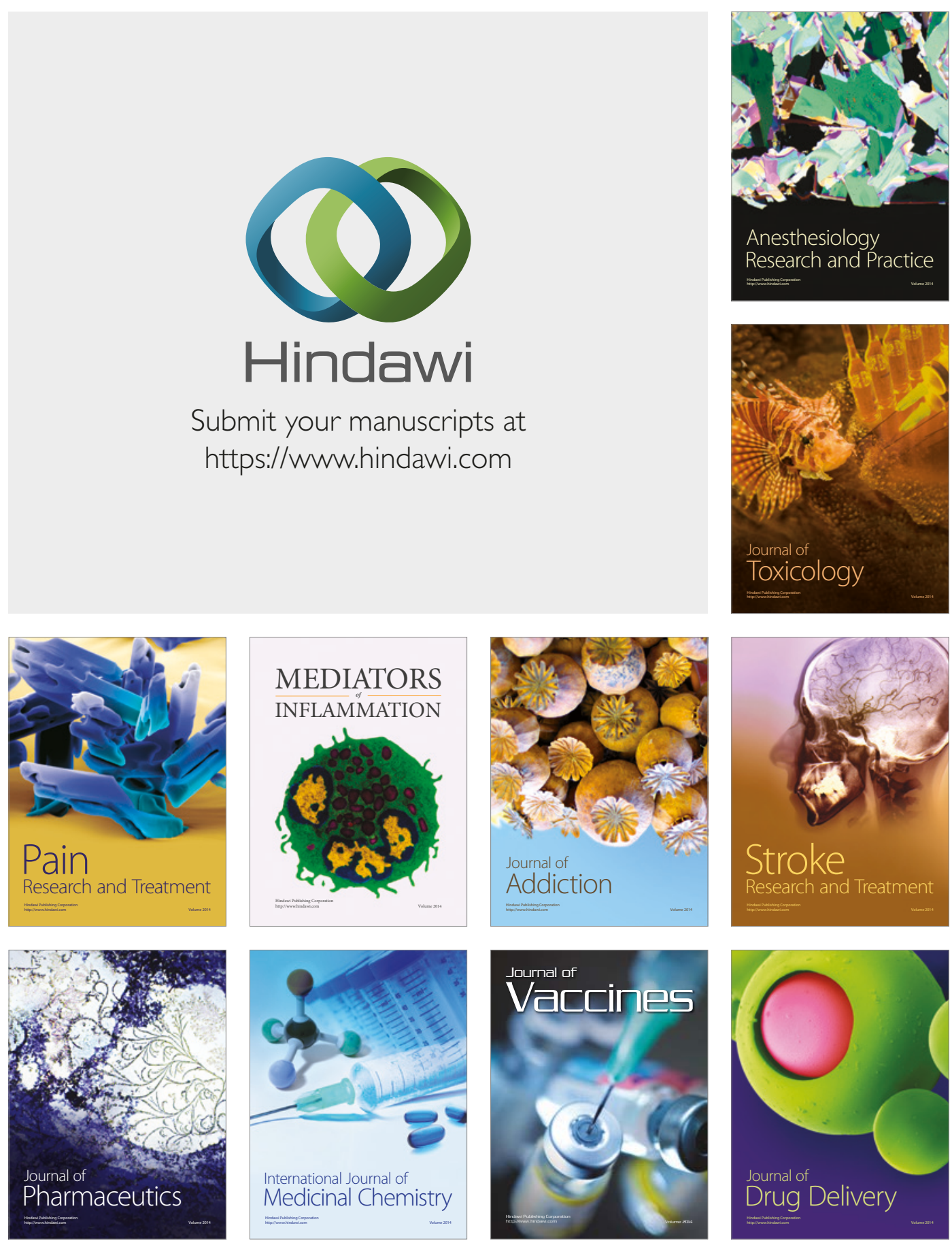